\title{
Applications of Biomaterials in 3D Cell Culture and Contributions of 3D Cell Culture to Drug Development and Basic Biomedical Research
}

\author{
Yujin Park ${ }^{1,2}$, Kang Moo Huh ${ }^{1, *,+}$ and Sun-Woong Kang ${ }^{2,3, *,+}$ (D) \\ 1 Department of Polymer Science and Engineering \& Chemical Engineering and Applied Chemistry, \\ Chungnam National University, Daejeon 34134, Korea \\ 2 Predictive Model Research Center, Korea Institute of Toxicology, Daejeon 34114, Korea \\ 3 Human and Environmental Toxicology Program, University of Science and Technology, Daejeon 34114, Korea \\ * Correspondence: khuh@cnu.ac.kr (K.M.H.); swkang@kitox.re.kr (S.-W.K.); \\ Tel.: +82-42-821-6663 (K.M.H.); +82-42-610-8209 (S.-W.K.); \\ Fax: +82-42-821-8910 (K.M.H.); +82-42-610-8157 (S.-W.K.) \\ $+\quad$ These authors contributed equally to this work.
}

check for updates

Citation: Park, Y.; Huh, K.M.; Kang, S.-W. Applications of Biomaterials in 3D Cell Culture and Contributions of 3D Cell Culture to Drug Development and Basic Biomedical Research. Int. J. Mol. Sci. 2021, 22, 2491. https:// doi.org/10.3390/ijms22052491

Academic Editor: Peter Illes

Received: 20 December 2020

Accepted: 25 February 2021

Published: 2 March 2021

Publisher's Note: MDPI stays neutral with regard to jurisdictional claims in published maps and institutional affiliations.

Copyright: (c) 2021 by the authors Licensee MDPI, Basel, Switzerland. This article is an open access article distributed under the terms and conditions of the Creative Commons Attribution (CC BY) license (https:// creativecommons.org/licenses/by/ $4.0 /)$.

\begin{abstract}
The process of evaluating the efficacy and toxicity of drugs is important in the production of new drugs to treat diseases. Testing in humans is the most accurate method, but there are technical and ethical limitations. To overcome these limitations, various models have been developed in which responses to various external stimuli can be observed to help guide future trials. In particular, three-dimensional (3D) cell culture has a great advantage in simulating the physical and biological functions of tissues in the human body. This article reviews the biomaterials currently used to improve cellular functions in 3D culture and the contributions of 3D culture to cancer research, stem cell culture and drug and toxicity screening.
\end{abstract}

Keywords: 3D cell culture; biomaterials; drug screening; alternative model

\section{Introduction}

The human body consists of highly sophisticated biological systems [1]. Cells form tissues in various combinations and patterns, tissues form organs with different types of tissues, and organs are organically connected to maintain the human body [2]. For a long time, two-dimensional (2D) cell culturing has been carried out on widely available flat plastic dishes to mimic the complex human body $[3,4]$. However, in a 2D culture system, the cells spread on the flat and hard surfaces and proliferate unnaturally. There is a difference in the cellular morphology, functions, and overall behavior compared to those in the natural environment [4]. In addition, the phenotype of the cell is not accurately reproduced in $2 \mathrm{D}$ culture. Indeed, chondrocytes grown in vitro to a large number gradually lose their differentiated phenotype, which is indicated by the loss of synthesis of type II collagen during 2D cell culture [5-7]. Similarly, 2D cultured primary human hepatocytes (PHHs) show rapid declines in critical phenotypic functions, such as cytochrome P-450 (CYP450) enzyme activities, insulin responsiveness, and expression of the master liver transcription factor hepatocyte nuclear factor $4 \alpha$ within hours to days [8]. Moreover, the transwell culture system, a kind of layered 2D culture system, was introduced as a co-culture system to simulate the in vivo environment, but this method has limitations in maintaining or improving cellular function over a long time $[9,10]$. Thus, cell culturing should be adapted to better reflect the natural environment.

Cells in the natural environment are embedded in the extracellular matrix (ECM), forming a complex three-dimensional (3D) structure [11]. The ECM plays the role of regulating cell-to-cell interactions, cell adhesion, differentiation, and growth [12-14]. Therefore, an understanding of ECM composition and structure is critical for the development of 
novel 3D cultures for predicting biological mechanisms and therapeutic effects. Mounting evidence has shown that physiologically more relevant factors can be revealed by imitation of the components and structure of the ECM in the natural environment $[13,15,16]$. In particular, cells cultured in a 3D microenvironment with ECM components showed realistic morphology and expressed several genes that failed to be expressed in a 2D culture [5-7]. Moreover, these cells synthesized ECM as they do in vivo for regeneration [11-14]. Thus, $3 \mathrm{D}$ cell culturing requires the use of biomaterials with a high level of similarity with the ECM for the enhancement of cellular functions.

A number of 3D culture systems are already available (Table 1). Biomaterials are available for 3D cell culture to improve the efficiency of culture and cell functions in various forms, including hydrogels, solid scaffolds, decellularized native tissue, and ultra-low attachment (ULA) surface (Figure 1). Knowledge of 3D culture methods has significantly increased, which has resulted in the development of numerous applications. Thus, this review addresses the applications of biomaterials in 3D cell culture and the contribution of $3 \mathrm{D}$ cell culture to cancer research, stem cell research, and drug and toxicity screening.

Table 1. Types of biomaterials used in three-dimensional (3D) cell culture and their advantages and disadvantages.

\begin{tabular}{|c|c|c|c|}
\hline Type & Advantage & Disadvantage & References \\
\hline Hydrogel & $\begin{array}{l}\text { Tissue like flexibility } \\
\text { Easily supplies water-soluble } \\
\text { factors to cells }\end{array}$ & $\begin{array}{l}\text { Low mechanical } \\
\text { resistance }\end{array}$ & {$[5,11,13,17,18]$} \\
\hline Solid scaffold & $\begin{array}{c}\text { Various materials can } \\
\text { be used } \\
\text { Physical strength is } \\
\text { easily adjusted }\end{array}$ & $\begin{array}{c}\text { Difficulty in } \\
\text { homogeneous dispersion } \\
\text { of cells }\end{array}$ & {$[15,16,19-21]$} \\
\hline $\begin{array}{l}\text { Decellularized } \\
\text { native tissue }\end{array}$ & $\begin{array}{c}\text { Provides complex } \\
\text { biochemistry, biomechanics } \\
\text { and 3D tissues of } \\
\text { tissue-specific extracellular } \\
\text { matrix (ECM) }\end{array}$ & $\begin{array}{l}\text { Decrease of mechanical } \\
\text { properties (roughness, } \\
\text { elasticity, and tension } \\
\text { strength) of the tissues as } \\
\text { compared to the } \\
\text { native group }\end{array}$ & [22-26] \\
\hline $\begin{array}{l}\text { Ultra-low } \\
\text { attachment } \\
\text { surface }\end{array}$ & $\begin{array}{l}\text { Provides an environment } \\
\text { similar to in vivo conditions }\end{array}$ & $\begin{array}{l}\text { Difficulty in mass } \\
\text { production } \\
\text { Lack of uniformity } \\
\text { between spheroids }\end{array}$ & [27-31] \\
\hline
\end{tabular}


A

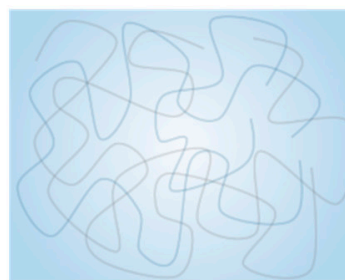

Hydrogel

B

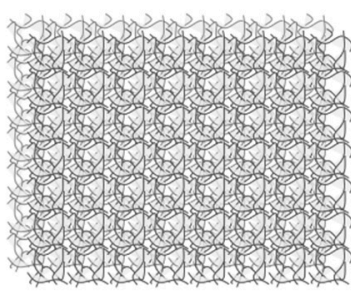

Sponge

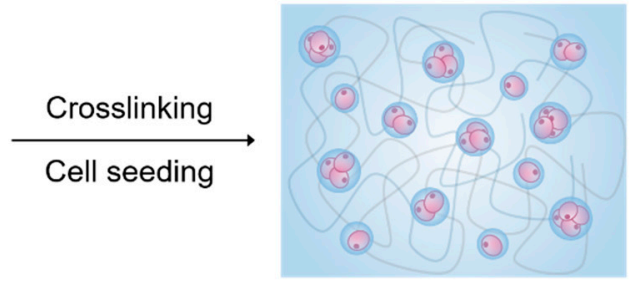

Cell encapsulation

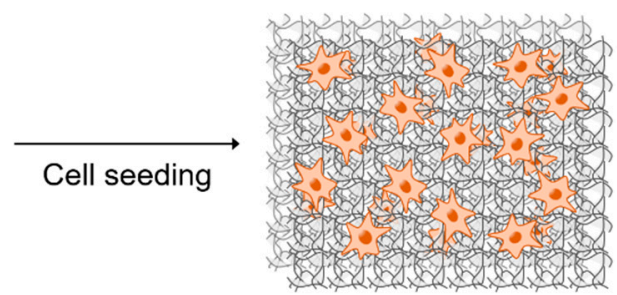

C
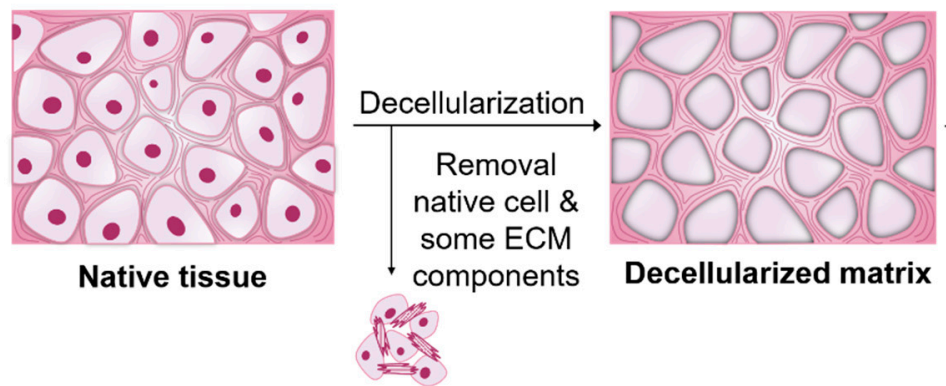

Decellularized matrix

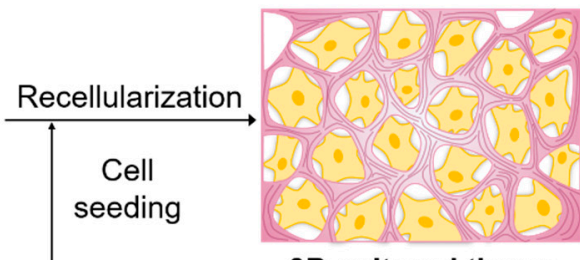

3D cultured tissue

D

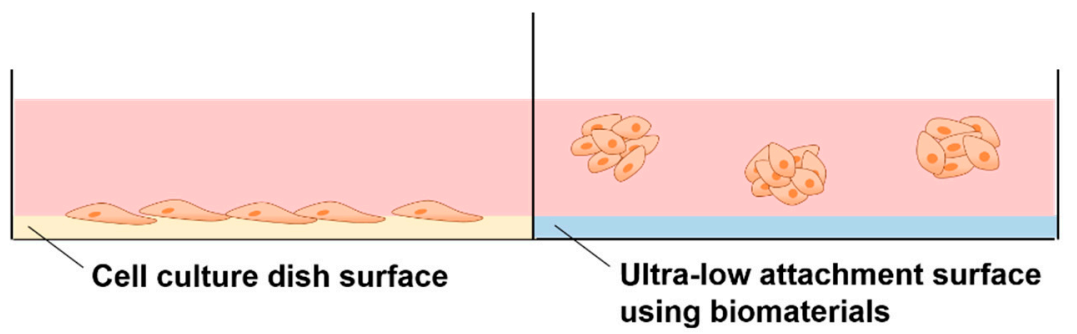

Figure 1. Biomaterials and related method of three-dimensional (3D) cell culture preparation. (A) Hydrogel, (B) Solid scaffold, (C) Decellularized native tissue (D) Ultra-low attachment surface.

\section{Applications of Biomaterials in 3D Cell Culture}

\subsection{Hydrogels}

Hydrogels have 3D structure, hydrophilic property, and polymeric networks capable of absorbing large amounts of water or biological fluids [32]. These hydrogels can mimic soft and wet environments similar to ECM of native tissues and promote the transportation of $\mathrm{O}_{2}$, nutrients, waste and soluble factors [33]. Therefore, they have received much attention in 3D cell culture [6,14]. Hydrogels are categorized as either synthetic or natural (Table 2). As the name suggests, synthetic hydrogels are composed of unnatural molecules such as poly vinyl alcohol (PVA), poly-2-hydroxyethyl methacrylate (pHEMA), and poly ethylene glycol (PEG). These materials can provide mechanical support for various types of cells [14]. However, they are biologically inert. In addition, they lack endogenous factors essential for cell behavior and act mainly as a template to permit cell function. Thus, synthetic hydrogels need modification with suitable biological components to promote 
signals of cellular function. On the other hand, synthetic hydrogels such as PEG represent a very good candidate for the encapsulation of various bioactive factors, drugs, and chemicals to avoid complicating systemic factors derived from hydrogels for a more controlled comparison of encapsulated materials [34]. Recently, it has been reported that the combination of arginine-glycine-aspartic acid (RGD) groups or alginate-PEG hydrogel improved the spread and proliferation of fibroblasts and enhanced the osteogenic differentiation of mesenchymal stem cells (MSCs) for 3D cell culture [35]. Similarly, PEG hydrogels were used to culture and expand a variety of neural and glial cell types simply by altering the material properties of the hydrogel [36].

Table 2. Synthetic and natural hydrogels for 3D cell culture.

\begin{tabular}{|c|c|c|c|c|}
\hline & Properties & Materials & Cells & Applications \\
\hline Synthetic & $\begin{array}{l}\text { Provide structural } \\
\text { support to various } \\
\text { cell types }\end{array}$ & $\begin{array}{c}\text { PVA } \\
\text { pHEMA } \\
\text { PEG }\end{array}$ & $\begin{array}{c}\text { Mouse } 129 \text { teratocarcinoma AT805 } \\
\text { derived cells (ATDC5) [37], Human iPS } \\
\text { cells (HPS0077) [38] } \\
\text { Bovine ear chondrocytes [39] } \\
\text { Ovarian Follicle cell [40], human } \\
\text { mesenchymal stem cells (hMSCs) [41] }\end{array}$ & $\begin{array}{c}\text { Repair cartilage [37], promote } \\
\text { differentiation [38] } \\
\text { Proliferate chondrocytes [39] } \\
\text { Promote cell survival, growth [40], and } \\
\text { viability by encapsulation [41] }\end{array}$ \\
\hline Natural & $\begin{array}{l}\text { Support cellular } \\
\text { activities and are } \\
\text { biocompatible and } \\
\text { biodegradable }\end{array}$ & Hyaluronic acid & $\begin{array}{l}\text { Human umbilical vein endothelial cells } \\
\text { (HUVECs) [42] } \\
\text { Human adipose-derived stem cells } \\
\text { (hASCs) [43], rat astroglioma } \\
\text { (LRM55) [44] } \\
\text { Human induced pluripotent stem } \\
\text { cell-derived neural progenitor cells } \\
\text { (hiPSC-NPCs) [45], human breast cancer } \\
\text { MCF-7 cells [46] }\end{array}$ & $\begin{array}{c}\text { Maintain their ability to secrete } \\
\text { therapeutic factors [43], maintain the } \\
\text { viability and function [44] } \\
\text { Promote neural differentiation [45], } \\
\text { higher tumorigenic capability of MCF-7 } \\
\text { cells [46] }\end{array}$ \\
\hline
\end{tabular}

Natural hydrogels are made up of natural substances such as collagen, alginate, hyaluronic acid and many more that promote several cellular functions with a range of endogenous factors present, which can benefit the viability, proliferation, and differentiation of many cell types [47-53]. However, due to the complexity and undefined nature of these hydrogels, it is difficult to very accurately determine which signals promote cellular function. Collagen is one of the abundantly present proteins in the ECM [54]. These compounds possess native tissue-like properties and characteristics. Thus, collagen can be used to create gels for 3D cell culture [48,55]. Collagen can be used in culturing various cell types to improve cell growth, adhesion, and differentiation. Cells can proliferate and form tissue-like structures within the collagen matrix [56]. Collagen plays an important role in maintaining the chondrocyte phenotype and supporting chondrogenesis, both in vitro and in vivo $[57,58]$. Previous studies have shown that type I collagen promotes the proliferation of chondrocytes and that type II collagen supports the chondrogenic differentiation of MSCs $[59,60]$. The results from this study suggest that there is clinical value in the cartilage repair capabilities of Col I/II hydrogel with encapsulated MSCs [61,62]. Nonetheless, the long-term performance of pure type I collagen may be compromised by significant shrinkage and weak mechanical properties $[63,64]$. To control these problems in collagen hydrogels, one possibility is to introduce additional molecular bonds between the collagen fibrils via different chemical cross-linkers. Lotz et al. aimed to improve the long-term stability and mechanical properties of collagen hydrogels by using the nontoxic chemical cross-linker four-armed succinimidyl glutarate polyethylene glycol (PEG-SG) to obviate negative impacts on cell viability. The hydrogels showed increased mechanical stability and compression E-modulus compared with pure collagen. This could indicate a more sterically rigid molecular network, rendering human dermal fibroblasts, and human epidermal keratinocytes unable to contract the hydrogel. This leads to a reproducible generation of full-thickness skin equivalents for in vitro testing or clinical application [65]. Incorporation of other materials into polymeric hydrogels can also be a suitable option to overcome these problems and improve the biological performance of the hydrogels. Sun et al. observed that 
collagen-chitosan could promote axonal regeneration and neurological recovery compared with collagen-chitosan hydrogels fabricated by traditional technology. In addition, it was demonstrated that 3D printing of collagen-chitosan decreased the formation of scars and cavities, and improved the regeneration of nerve fibers as well as functional recovery in rats $[66,67]$. Ying et al. fabricated a porous structure of this collagen-hyaluronic acid (HA) hydrogel that contributed to water retention, gas exchange, nutrition penetration, and cell dwelling [68]. In addition, these materials are suitable to study tissue reconstruction by seeding co-cultures of fibroblasts and endothelial cells within the collagen matrix [69]. In this system, fibroblasts form connective tissue, and endothelial cells produce angiogenic growth factors and vasculature.

Hyaluronic acid (HA) is distributed in many tissues, such as skin and cartilage [70]. HA can be obtained not only from animal tissues, but also via microbial fermentation in Escherichia coli to produce animal-free HA [71]. The role of HA in tissue is to promote cellular survival, migration, angiogenesis, and differentiation by transduction of intracellular signals [72-74]. In addition, the higher content of HA present in the cancer microenvironment promotes tumor progression and resistance to anticancer drugs $[75,76]$. Tumor cells showed decreased adhesion to the surface of HA. These properties promote the production of tumor spheroids and mimic cell HA signaling in the tumor microenvironment for anticancer drug screening purposes. Ahrens et al. reported that HA promotes the growth rate of melanoma cells by enhancing the secretion of basic fibroblast growth factor (bFGF) [77]. Other researchers have reported that when cells are 3D cultured in the presence of HA, the activity of multidrug resistance proteins is enhanced and therapeutic effectiveness is reduced compared to the 2D cultured cells [78]. Another interesting application of HA hydrogel is to improve the efficacy of 3D cell culture by mixing these materials with various substances. Lou et al. reported that HA-collagen hydrogels promoted cell spreading, fiber remodeling, and focal adhesion in 3D cell culture [49]. Häckel and coworkers demonstrated that human nucleus pulposus cells cultured in fibrin-HA hydrogels showed an increase in collagen type II and carbonic anhydrase XII gene expression [79]. Furthermore, Lee et al. also reported that chitosan/HA blend hydrogels exhibited enhanced physical stability, mechanical properties, cell binding affinity, and tissue compatibility [80]. Recently, HA combined with alginate and fibrin has been used as a bioink for 3D bioprinting of peripheral nerve tissue regeneration [81]. Finally, acetylated HA (AcHA) was used to enhance the mechanical strength of the thermogel via simple blending of modified glycol chitosan. The blended gel showed not only good cell binding affinity in vitro and biocompatibility in vivo, but also more effective cartilage formation than that of the original hydrogel [80].

Alginate is derived from the cells of brown algae, and its monomers have the ability to cross-link to form hydrogels [50]. Normally, alginate does not interact directly with mammalian cells and is not degradable [82]. Thus, when hydrogels exhibiting minimal degradation are desired, alginate is selected for these studies. In addition, cell adhesion can be improved via covalent coupling of the RGD cell adhesion peptide to the alginate chains [83]. A previous study reported a material approach to tune the rate of stress relaxation of hydrogels for 3D culture, independent of the hydrogel's initial elastic modulus, cell adhesion ligand density, and degradation. The influence of substrate stress relaxation on cell spreading and proliferation was enhanced when RGD cell adhesion and ligand density was increased in gels with faster relaxation [84]. Another study reported that stem cells encapsulated in ionically crosslinked alginate hydrogels undergo predominantly adipogenic differentiation at initial moduli of $1-10 \mathrm{kPa}$ and predominantly osteogenic differentiation at initial moduli of 11-30 kPa [85]. Recently, alginate hydrogels have been extensively used as bioinks to provide 3D cell growth because of their relatively higher viscosity and rapid crosslinking process after printing [86,87]. In addition, oxidized alginates showed great potential as ink for bioprinting [88]. Finally, alginate hydrogels encapsulating stem cells have been investigated for the prevention of immune rejection of transplanted cells $[89,90]$. Stock and coworkers reported that alginate capsules prevented 
infiltration of immune cells while allowing smaller molecules, such as oxygen, nutrients, glucose, and insulin to diffuse freely through the capsule [91].

\subsection{Porous and Fibrous Scaffolds}

Solid scaffold-based cell culturing is one of the older techniques used in the field of 3D cell culture [92]. In this system, scaffolds may facilitate proliferation, cell adhesion, and signaling activities between the cells. These efficacies of a scaffold are affected by the materials that make up the scaffold and its physical structures, such as exposed surface, pore size, pore distribution, and interconnectivity (Table 3 ). These solid scaffolds are mainly porous foams or fibrous meshes fabricated from synthetic polymers, such as poly(glycolic acid) (PGA), poly(lactic acid) (PLA), poly(lactic-co-glycolic acid) (PLGA), and polycaprolactone (PCL), and naturally derived polymers, such as collagen, hyaluronic acid, fibrin, alginate, gelatine, silk, and chitosan [93-99].

Table 3. Fabrication of porous scaffolds: advantages and disadvantages.

\begin{tabular}{cccc}
\hline Method & Advantages & Disadvantages & References \\
\hline Particulate Leaching & $\begin{array}{c}\text { Modulate pore size } \\
\text { and porosity }\end{array}$ & $\begin{array}{c}\text { Limited pore shape } \\
\text { and size }\end{array}$ & {$[15]$} \\
\hline Solvent Casting & $\begin{array}{c}\text { Modulate pore size } \\
\text { and porosity } \\
\text { Easy incorporation of drugs } \\
\text { within the scaffold }\end{array}$ & $\begin{array}{c}\text { Low pore } \\
\text { interconnectivity }\end{array}$ & {$[100,101]$} \\
\hline Emulsion Templating & $\begin{array}{c}\text { Modulate particle size, high } \\
\text { porosity, interconnectivity }\end{array}$ & $\begin{array}{c}\text { Difficulty in } \\
\text { obtaining emulsions } \\
\text { with sufficient } \\
\text { monodispersity for } \\
\text { crystallization }\end{array}$ & {$[16,102,103]$} \\
\hline Gas Foaming & Modulate pore size \\
and porosity & Free of toxic organic solvents & $\begin{array}{c}\text { Unexpected pore } \\
\text { interconnectivity }\end{array}$ & {$[104-106]$} \\
\hline Melt Molding & Modulate pore size \\
and porosity & $\begin{array}{c}\text { High temperature } \\
\text { required when } \\
\text { molding }\end{array}$ & {$[107]$} \\
\hline
\end{tabular}

Porous foam-solid scaffolds have high porosity and a uniform interconnected structure. Many attempts have been made to fabricate porous foam-solid scaffolds [108,109]. Particulate leaching is a physical process that involves casting polymers around soluble beads known as porogens [100]. Solvent casting uses a polymer dissolved in an organic solvent. This solution is mixed with ceramic particles and poured into a predefined 3D mold, which is left to set. The solvent casting and particulate leaching (SCPL) method, which combines the particulate leaching method and solvent casting method, has been used to produce scaffolds for the culture of osteoblasts and osteogenic differentiation of stem cells [110]. Mouse embryonic osteoblast cells (MC3T3-E1) cultured on PLGA scaffolds made with the SCPL method showed increased alkaline phosphatase activity and expression of type I collagen [111]. Emulsion templating is one of the common methods for the fabrication of porous scaffolds [16]. Porous polymers can be generated within high internal phase emulsions. It has been reported that metabolic activity is improved when hepatocytes are cultured on PCL scaffolds containing various factors by emulsion templating $[112,113]$. The gas forming technique is performed by agitating the polymer and creating foam [104]. High-pressure gases such as $\mathrm{CO}_{2}$ can be used as the gas foaming agent, and the porosity of the scaffold can be controlled by the amount of gas dissolved in the polymer. The melt molding method uses both polymer and porogen, which are poured into a mold and heated above the polymer glass transition temperature $[107,114]$. Various types of cells have been successfully cultured in 3D on porous solid scaffolds [115-118]. 
Vascular smooth muscle cells adhered to and proliferated in engineered smooth muscle tissue on highly porous and elastic tubular scaffolds [119]. Human hepatoma cells showed higher cell infiltration in PLGA scaffold fabricated by the gas foaming method. The porous PLGA scaffold fabricated by the particulate leaching method supported cell adhesion and growth. After implantation, there was better bone and cartilage formation inside the scaffold [120,121].

Fibrous scaffolds provide a large surface area for cell growth in 3D cell culture (Table 4). These structures allow appropriate space for gas and nutrition exchange and cell infiltration. In addition, fibrous scaffolds can imitate oriented and aligned tissues, which include skeletal muscles, the central nervous system, and cardiac tissues [122-126]. Accordingly, the aligned fibers help control stem cell differentiation into the desired cell type [127-130]. Several natural and synthetic polymers, including collagen, gelatine, hyaluronic acid, alginate, chitosan, silk, PLA, PLGA, and others, have been used for the fabrication of fibrous scaffolds $[124,129,131,132]$. The fiber mesh is either knitted or woven into 3D patterns of different pore sizes [133]. However, these materials do not have sufficient mechanical and structural stability. Fiber bonding was thus developed to overcome the drawbacks of fiber mesh. Enhanced mechanical strength is provided by binding the fibers at the joints or intersections by raising temperatures above the polymer melting points or by using special solvents [134]. The electrospinning method uses an electric field generated using two electrodes (one each placed in the polymer and collector solutions) having electric charges of opposite polarity for the production of continuous fibers ranging from submicron to nanomicron diameters. This system allows cells to adhere and elongate along the fibers, which induces cell alignment and directionality in the cultures [135]. Lee et al. fabricated PLLA fibrous scaffolds using the electrospinning method, and their morphologies were controlled by the fiber collection speed. Therefore, the morphology of the designed fibrous scaffolds in this work has successfully controlled cell alignment as well as the direction of calcification [136]. For phase separations, two phases that are polymer rich and polymer poor are formed upon the addition of water, inducing phase separation $[137,138]$. Upon cooling below the solvent melting point followed by vacuum drying, the scaffold is obtained. This method can easily be combined with other fabrication technologies, such as particulate leaching, to design 3D structures with the desired pore morphology. Finally, nanofibers can be generated by the self-assembly of synthetic or natural molecules $[139,140]$. These scaffolds fabricated by self-assembly facilitated attachment and migration of hepatocytes, stem cells, and endothelial cells [141,142].

Table 4. Fabrication of fibrous scaffolds: advantages and disadvantages.

\begin{tabular}{cccc}
\hline Method & Advantages & Disadvantages & References \\
\hline Fiber Mesh & $\begin{array}{c}\text { High surface area for } \\
\text { cell attachment }\end{array}$ & $\begin{array}{c}\text { Low structural } \\
\text { stability }\end{array}$ & {$[21]$} \\
\hline Fiber Bonding & $\begin{array}{c}\text { High surface to } \\
\text { volume ratio, high } \\
\text { porosity }\end{array}$ & $\begin{array}{c}\text { Limited applications } \\
\text { to other polymers }\end{array}$ & {$[132]$} \\
\hline Electrospinning & $\begin{array}{c}\text { Induces cell } \\
\text { alignment and } \\
\text { directionality }\end{array}$ & $\begin{array}{c}\text { Limited by cell } \\
\text { seeding }\end{array}$ & {$[143-145]$} \\
\hline Phase Separation & $\begin{array}{c}\text { No reduction in the } \\
\text { activity of molecules }\end{array}$ & $\begin{array}{c}\text { Difficult to control the } \\
\text { scaffold morphology }\end{array}$ & {$[138,146]$} \\
\hline Self-Assembly & $\begin{array}{c}\text { Form extremely } \\
\text { stable scaffolds, less } \\
\text { use of organic solvent }\end{array}$ & $\begin{array}{c}\text { Expensive material, } \\
\text { complicated and } \\
\text { elaborate process }\end{array}$ & {$[147,148]$} \\
\hline
\end{tabular}

Another way to fabricate a porous scaffold is 3D printing. This method allows for easier and more detailed manufacturing than the above two methods and allows various 
architectures and control of mechanical stability [149]. The method can be applied to bone tissue engineering by taking advantage of its strong mechanical strength [150]. Chitosan material, which has been used as a soft scaffold in the form of a conventional hydrogel, can also be used for bone tissue engineering after reinforcement of its mechanical strength by applying this method. This can be done by incorporating a chitosan thermogel into a porous PCL scaffold [151].

\subsection{Decellularized Native Tissue}

One of the ideal scaffolds is a decellularized matrix that provides natural geometric morphology, flexibility, and mechanical strength, which is difficult to mimic perfectly with synthetic scaffolds. Recently, various approaches have been introduced to fabricate decellularized scaffolds, including perfusion of the whole organ (recommended for dense organs/tissues), application of a pressure gradient (employed for hollow tissues), use of supercritical fluid (appropriate for long-standing storage of decellularized scaffolds), and immersion and agitation (suitable for thin tissues) [152-157]. During the decellularization process, the cells are eliminated to inhibit inflammatory reactions or immediate rejection after implantation. The ECM derived from decellularized matrix provides an endogenous environment, from a biochemical and anatomical point of view, for regeneration of target organs. Recellularization is performed by direct injection of cells into the vein because of its proper vascular diameter and accessibility. This method is broadly used for blood vessel recellularization of different organs, such as the heart, lungs, and liver [158-160]. Another approach for recellularization is cell inoculation into mass media by allowing cells to recover through the circuit to seed scaffolds, but the efficiency of this method is lower than that of direct injection using veins [161]. In various studies, researchers investigated the effect of decellularized scaffolds on cell proliferation and construction of organs, including the liver, heart, lung, kidney, and pancreas [162-167].

\subsection{Ultra-Low Attachment Surface}

Cell culture plates can be covered with biomaterials with low cell-binding properties to prevent the cells from adhering to the surface. This method is one of the older techniques to generate self-assembled cellular structures in media for 3D cell culture. This system inhibits the attachment of cells to the surface of the culture plate, resulting in force floating of cells. Force floating improves cell-to-cell interactions, enabling multicellular aggregation. To provide attachment-resistant cell surfaces, cell culture plates or surfaces are coated with polymers that possess low cell-binding properties, such as 2-hydroxyethyl methacrylate (poly-HEMA), polyethylene glycol, chitosan, agar, and agarose [168-172]. These polymers allow greater cell-cell interactions rather than cell-substrate interactions, which enables spontaneous spheroid formation [173]. Cell culture plates could have flat or round surfaces. The flat surface causes the formation of irregularly sized spheroids. However, round surfaces are capable of generating single spheroids. Various types of cells have successfully formed spheroids on plates or round surfaces with low cell-binding properties [174-178]. In this system, cells accumulate as clusters and synthesize their own ECM. In addition, the signaling and communication between cells in spheroids were enhanced, and gap junctions were created that can facilitate the exchange of ions, small molecules and electrical currents. This method can be used for high-throughput screening [179]. Recently, Cho et al. fabricated new polymers with low cell-binding properties for spheroid generation [180]. Spontaneous spheroid formation was completed within a few days, and the size of the spheroids varied with the cell density.

\section{Applications of Three-Dimensional Cell Culture}

\subsection{Cancer Research and Drug Screening}

Three-dimensional (3D) cell culture has several applications in the field of biological science. These applications can be divided into three categories: cancer research, stem cell culture, and drug toxicity and screening. With the growing demand for effective 
validation in the field of oncology, there is a demand for research tools that provide clinically significant results for safety and efficacy testing of anticancer drugs. Moreover, 3D culture techniques have been able to produce 3D models, such as oncospheres, spheroids, and other tumor models that closely resemble the natural tumor microenvironment due to the proper supply of nutrients, oxygen, and intercellular interactions [181,182]. Increasing the scope of this technology could reduce the number of animals sacrificed for research. In addition, various meaningful results that could not be solved with animal models can be obtained.

Animal models and 2D culture systems have been a standard to determine anticancer drug effects on growth inhibition and apoptosis. However, the results produced from these systems showed relatively low similarity in clinical outcomes $[183,184]$. Owing to their close resemblance to tumor microenvironments, 3D culture systems are gradually being used to replace animal and 2D culture models for screening anticancer drugs that are in their initial stages of development. The spheroids contain proliferating cells on the surface and quiescent cells in the core due to limited penetration of nutrients and oxygen, and necrotic areas may be included in larger spheroids that resemble native solid tumors $[185,186]$. Several studies have shown differences in viability in 2D- and 3D-cultured cancer cells $[187,188]$. The cells were treated with the same concentration of tirapazamine (TPZ). Cells cultured in 2D were more resistant to treatment with TPZ and showed $72 \%$ viability. In contrast, cells cultured in $3 \mathrm{D}$ were more responsive to treatment with TPZ, with $40 \%$ viability. The difference was correlated with the fact that TPZ is a hypoxic activated cytotoxin, which works more effectively on cells cultured in 3D because the core of the spheroid is hypoxic due to limited oxygen diffusion. Some studies have reported that cancer cells in 3D models show increased drug resistance compared to those in 2D culture [189]. The variation in response to drugs can be explained by limitations on the mass transfer of the drugs in 3D culture systems compared to 2D cultured cells [190,191].

Cancer cells grown and maintained in 3D models show phenotypic heterogeneity [192]. This is important because cells of the same tumor group also change morphologically and functionally as gene expression, differentiation and proliferation rates change. Due to the diversity of cancer cells, it is difficult to develop drugs that accurately target tumor cells. In this regard, appropriate genetic modifications of ovarian epithelial cancer in a 3D environment have been investigated during development and progression [193-195]. Therefore, 3D models are used to study changes in gene expression-related tumor microenvironments. Moreover, 3D cell culture was used to confirm the presence of cancer stem cells [196]. Numerous studies have demonstrated that cancer stem cells can generate tumor-spheres by a suspension of single cells in serum-free conditions. Thus, scaffold-free methods are being used for 3D culture of cancer stem cells. In addition, 3D coculture of cancer cells and normal cells was used to confirm the specificity of drugs for cancer cells [197,198]. These studies suggest the possibility of 3D models in anticancer drug screening to more accurately represent tumor models.

\subsection{Stem Cell Research and Drug Screening}

Recently, stem cells have become an important research tool in biology, medicine and toxicology, leading to a rapidly developing new scientific field. The importance of stem cells is evidenced by the increasing number of articles published each year. This rapid development requires new means of providing high-quality, well-defined and scalable techniques for the generation of stem cells. It is essential to proliferate stem cells to be used as a tool in scientific disciplines. Embryoid bodies (EBs) are 3D aggregates generated in suspension by pluripotent stem cells (PSCs), including embryonic stem cells (ESCs) and induced pluripotent stem cells (iPSCs) [199]. EB differentiation is a common tool to generate specific cell lineages from PSCs $[200,201]$. Many 3D culture methods of PSCs in the form of EBs have been developed. Conventional methods for forming EBs include scaffold-free methods such as the ultra-low attachment (ULA) method, hanging drop methods, and suspension culture methods. In particular, EB formation can be more accurately controlled 
by the inoculation of known cell numbers within single drops suspended from the lid of a Petri dish $[199,202]$. While this method enables control of EB size by altering cell density per drop, the formation of hanging drops is labor intensive and does not facilitate scalable cultures. Additionally, the media cannot be readily exchanged without disturbing the EBs every 2-3 days. Recently, new methods have been developed to enable media exchange using a modified hanging drop plate [203]. In addition, these methods have also been designed to readily separate EBs within individual wells on adhesive substrates for the analysis of EBs [204,205]

One of the major efforts in the stem cell field is to develop therapeutic applications for the regeneration of diseased, dysfunctional or complex injured tissues. To that end, it is essential to secure technology for stem cell proliferation with increased cell viability and differentiation potential [206]. Various studies have been conducted to prove the convenience of direct transplantation, improved graft adherence, and increased cellular loading densities through 3D cell culture [207]. Studies have reported hydrogel encapsulation in $3 \mathrm{D}$ cell culture for regeneration of cartilage, bone, liver, cardiac, cortical, brain, and skin tissues [208-214]. This method facilitates cell growth, differentiation and migration of many cell types, such as neural stem cells, mesenchymal stem cells, adipose-derived stem cells, and PSCs. In addition, hydrogels with stem cells have demonstrated therapeutic effects in xenograft models [215].

Three-dimensional (3D) cell culture has emerged as a promising method for the generation of organoids that could serve as a model to study various disease mechanisms or the toxicity of new drugs (Figure 2). Organoids are highly heterogeneous 3D structures that exhibit typical tissue architecture. Thus, organoids can serve as a valuable developmental model to explore new drugs $[216,217]$. To date, several protocols have been developed for the in vitro generation of organoids for the brain, gut, retina, liver, skin, and kidney [218-222]. Organoid formation generally requires culturing stem cells or progenitor cells in a 3D environment $[223,224]$. Hydrogels such as Matrigel or collagen gel are used to provide a 3D environment. When stem cells are used for the creation of the organoid, cells are allowed to form embryoid bodies. These embryoid bodies are an example of organoids. Cardiac organoids generated from cardiomyocytes have the ability to spontaneously contract [225]. These can produce electrophysiological measurements when plated on multielectrode arrays. Hairy human skin can be generated using a unique approach of organoid formation. PSCs can be differentiated into epidermis, dermis, fat, nerves and hair buds that produce hair [226]. Several studies have shown that more realistic outcomes can be achieved to study disease mechanisms by organoids and how cells respond to drug treatments $[227,228]$. However, standard protocols of organoid generation have yet to be defined. Therefore, the development of organoid culture platforms for largescale production, organoid-based high-content screening platforms, and finely controlled systems should be continued. Finally, developing organoids generated from PSCs in an organ-on-chip system is also an area to be explored. The function of various organs or tissues, such as the lung, liver, kidney, heart, and gut, can be realized by using microfluidic device technology in an organ-on-chip system $[229,230]$. The successful development of organ-on-chip system will be able to mimic the systemic circulation of humans and animals under in vitro conditions and will provide us with vast benefits as an alternative model for drug screening and toxicology tests. 


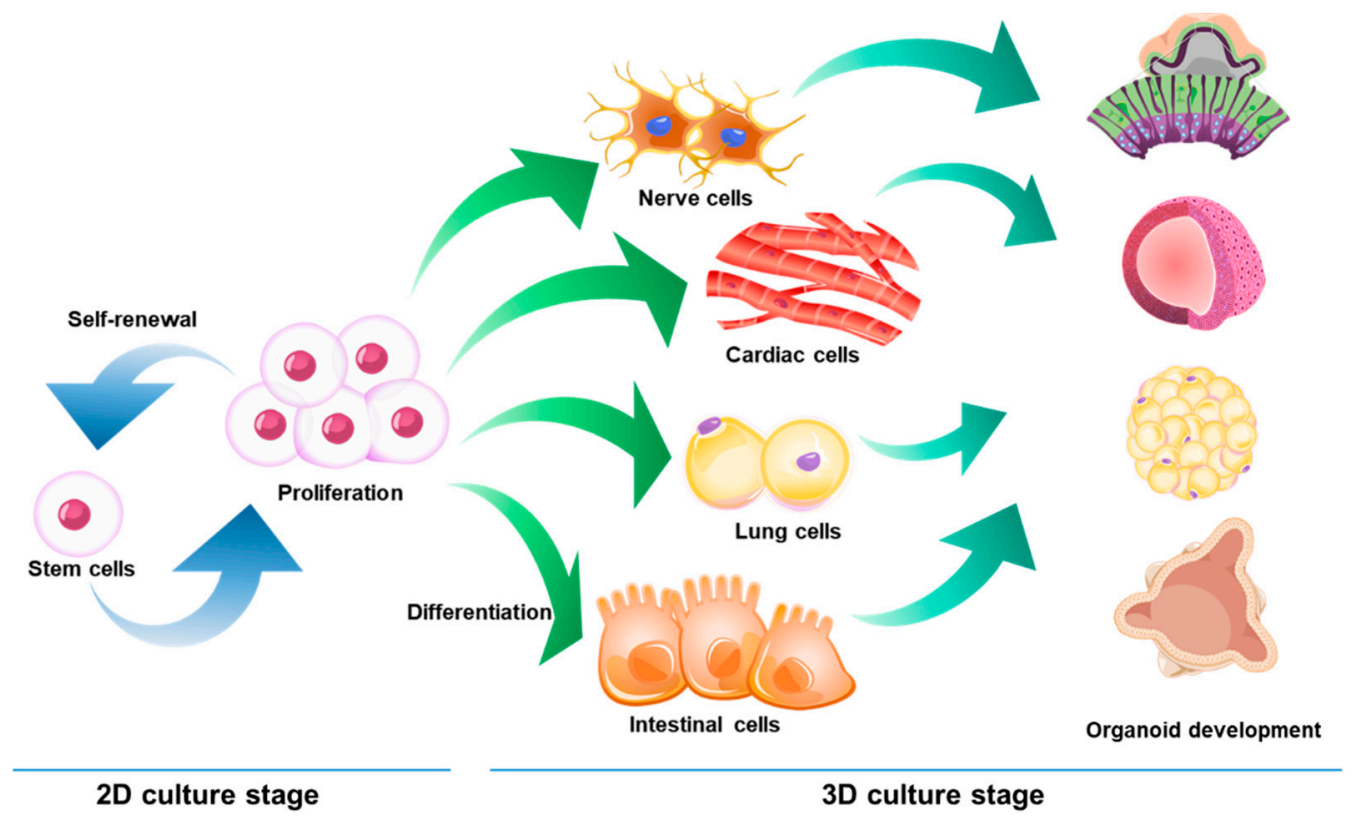

Figure 2. Stem cell-derived organoids.

\section{Conclusions and Future Perspectives}

Herein, we introduced 3D cell culture methods and summarized the trends in the application of this technology. The 3D cell culture technologies have already emerged as an important tool that can facilitate research in the biomedical field with more realistic results. However, 3D culture methods have many problems to overcome. First, there are no standardized culture methods. The 3D cell culture method is more difficult and more complicated than that of $2 \mathrm{D}$ cell culture. Thus, it has low reproducibility and requires a high level of skill. The second problem is that $3 \mathrm{D}$ cell culture is still inappropriate for completely simulating the intrinsic properties of cells. One example is a vascular problem. In the body, tissues are constantly supplied with nutrients and oxygen from microvessels in the tissues. Cells cannot survive beyond $150 \mu \mathrm{m}$ from a microvessel. Thus, angiogenesis is an important consideration for successful 3D cell culture. When tissue is regenerated in vitro, the 3D tissue should be supplied with nutrients and oxygen around it until blood vessels grow into the tissue. In this case, growth factors as well as vascular endothelial cells and stem cells may be used to promote angiogenesis. However, the problem is that necrosis can occur before blood vessels are formed due to the insufficient supply of nutrients and oxygen within the 3D tissue. Finally, even if this simulation is correctly achieved, there is still a lack of research on analytical methods for verification. Most analyses now depend on visual images. Therefore, it can be difficult to clearly judge the standards and grasp the characteristics inside 3D structures. For this reason, standardization of the analysis of $3 \mathrm{D}$ cell culture is still difficult. Although there are still many problems to overcome in 3D cell culture, the introduction of advanced 3D cell culture technologies has attracted several researchers to shift their attention from $2 \mathrm{D}$ to $3 \mathrm{D}$ cell culture systems. Thus, 3D cell culture technology is expected to contribute greatly to future research with the potential to create excellent outputs.

Author Contributions: All authors have contributed to the conceptualization, writing and approved the final version of this manuscript. All authors have read and agreed to the published version of the manuscript.

Funding: This research was supported by the Bio\&Medical Technology Development Program (NRF-2016M3A9B4919655 and NRF-2019M3A9H1103331) and Basic Science Research Program (NRF2020R1A2C2100794) of the National Research Foundation funded by the Korean government. 
Acknowledgments: We thank Hye-Eun Shim (Research Group for Biomimetic Advanced Technology, KIT) for technical support in illustration of Figure 2.

Conflicts of Interest: The authors declare no conflict of interest.

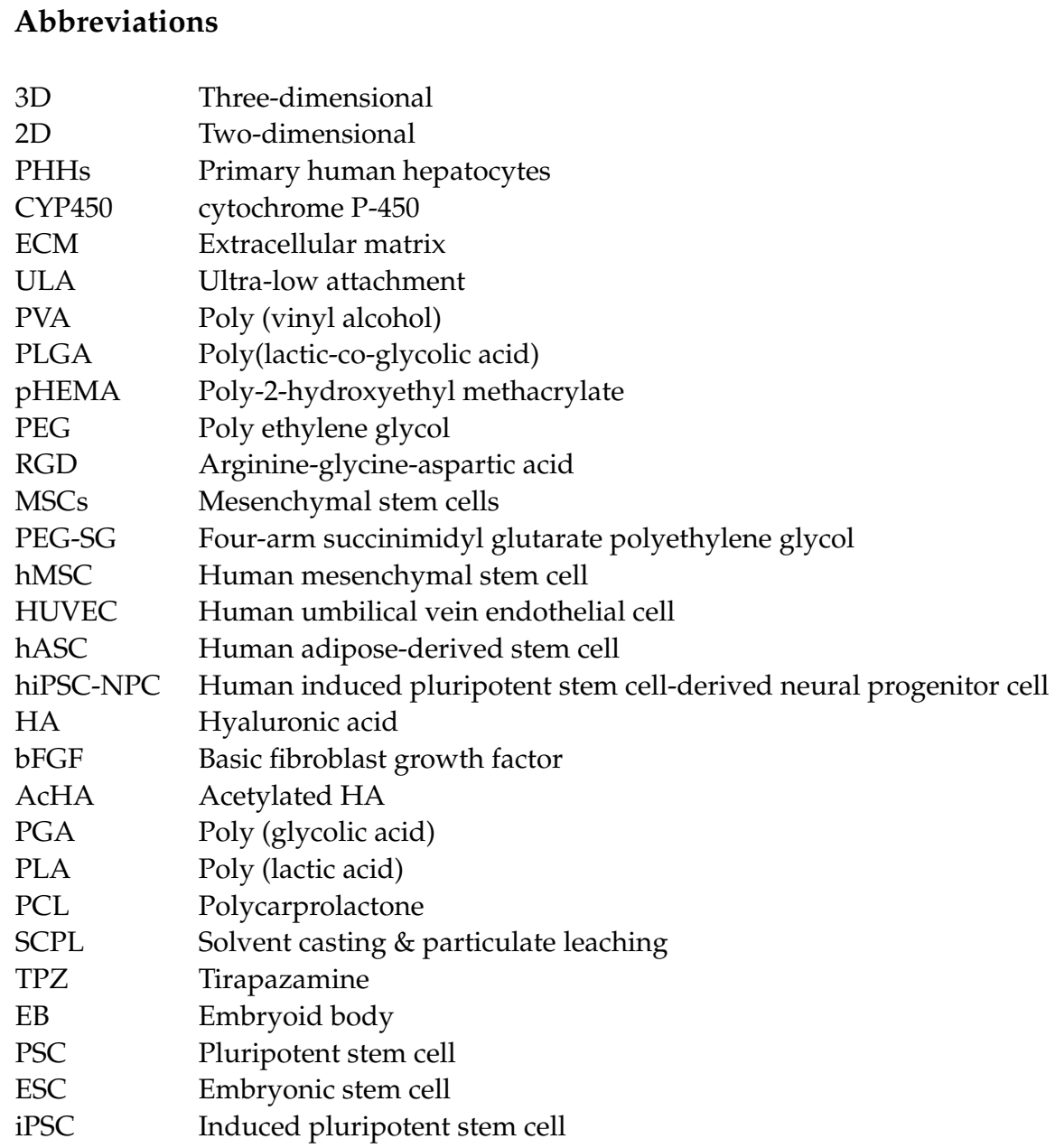

\section{References}

1. Acosta, D.; Anuforo, D.C.; Smith, R.V. Cytotoxicity of acetaminophen and papaverine in primary cultures of rat hepatocytes. Toxicol. Appl. Pharmacol. 1980, 53, 306-314. [CrossRef]

2. Baharvand, H.; Hashemi, S.M.; Ashtiani, S.K.; Farrokhi, A. Differentiation of human embryonic stem cells into hepatocytes in 2D and 3D culture systems in vitro. Int. J. Dev. Biol. 2006, 50, 645-652. [CrossRef]

3. Knight, E.; Przyborski, S. Advances in 3D cell culture technologies enabling tissue-like structures to be created in vitro. J. Anat. 2015, 227, 746-756. [CrossRef]

4. Xu, K.-P.; Li, X.-F.; Yu, F.-S.X. Corneal Organ Culture Model for Assessing Epithelial Responses to Surfactants. Toxicol. Sci. 2000, 58, 306-314. [CrossRef]

5. Caliari, S.R.; Burdick, J.A. A practical guide to hydrogels for cell culture. Nat. Methods 2016, 13, 405-414. [CrossRef]

6. Sepantafar, M.; Maheronnaghsh, R.; Mohammadi, H.; Radmanesh, F.; Hasani-Sadrabadi, M.M.; Ebrahimi, M.; Baharvand, H. Engineered Hydrogels in Cancer Therapy and Diagnosis. Trends Biotechnol. 2017, 35, 1074-1087. [CrossRef]

7. Debnath, T.; Ghosh, S.; Potlapuvu, U.S.; Kona, L.; Kamaraju, S.R.; Sarkar, S.; Gaddam, S.; Chelluri, L.K. Proliferation and differentiation potential of human adipose-derived stem cells grown on chitosan hydrogel. PLoS ONE 2015, 10, e0120803. [CrossRef] [PubMed]

8. Ware, B.R.; Durham, M.J.; Monckton, C.P.; Khetani, S.R. A Cell Culture Platform to Maintain Long-term Phenotype of Primary Human Hepatocytes and Endothelial Cells. Cell. Mol. Gastroenterol. Hepatol. 2018, 5, 187-207. [CrossRef] [PubMed]

9. Hira, V.V.V.; Breznik, B.; van Noorden, C.J.F.; Lah, T.; Molenaar, R.J. 2D and 3D in vitro assays to quantify the invasive behavior of glioblastoma stem cells in response to SDF-1 $\alpha$. BioTechniques 2020, 69, 339-346. [CrossRef]

10. Noonan, J.; Grassia, G.; MacRitchie, N.; Garside, P.; Guzik, T.J.; Bradshaw, A.C.; Maffia, P. A Novel Triple-Cell Two-Dimensional Model to Study Immune-Vascular Interplay in Atherosclerosis. Front. Immunol. 2019, 10, 849. [CrossRef] [PubMed] 
11. Benoit, D.S.; Schwartz, M.P.; Durney, A.R.; Anseth, K.S. Small functional groups for controlled differentiation of hydrogelencapsulated human mesenchymal stem cells. Nat. Mater. 2008, 7, 816-823. [CrossRef]

12. Frantz, C.; Stewart, K.M.; Weaver, V.M. The extracellular matrix at a glance. J. Cell Sci. 2010, 123, 4195-4200. [CrossRef]

13. Tibbitt, M.W.; Anseth, K.S. Hydrogels as extracellular matrix mimics for 3D cell culture. Biotechnol. Bioeng. 2009, 103, 655-663. [CrossRef]

14. Dikovsky, D.; Bianco-Peled, H.; Seliktar, D. The effect of structural alterations of PEG-fibrinogen hydrogel scaffolds on 3-D cellular morphology and cellular migration. Biomaterials 2006, 27, 1496-1506. [CrossRef] [PubMed]

15. Wu, L.; Jing, D.; Ding, J. A "room-temperature" injection molding/particulate leaching approach for fabrication of biodegradable three-dimensional porous scaffolds. Biomaterials 2006, 27, 185-191. [CrossRef] [PubMed]

16. Dikici, B.A.; Claeyssens, F. Basic Principles of Emulsion Templating and Its Use as an Emerging Manufacturing Method of Tissue Engineering Scaffolds. Front. Bioeng. Biotechnol. 2020, 8, 875. [CrossRef]

17. Hunt, N.C.; Hallam, D.; Karimi, A.; Mellough, C.B.; Chen, J.; Steel, D.H.W.; Lako, M. 3D culture of human pluripotent stem cells in RGD-alginate hydrogel improves retinal tissue development. Acta Biomater. 2017, 49, 329-343. [CrossRef] [PubMed]

18. King, W.J.; Jongpaiboonkit, L.; Murphy, W.L. Influence of FGF2 and PEG hydrogel matrix properties on hMSC viability and spreading. J. Biomed. Mater. Res. A 2010, 93, 1110-1123. [CrossRef] [PubMed]

19. Maximova, N.; Österberg, M.; Koljonen, K.; Stenius, P. Lignin adsorption on cellulose fibre surfaces: Effect on surface chemistry, surface morphology and paper strength. Cellulose 2001, 8, 113-125. [CrossRef]

20. Hochleitner, G.; Chen, F.; Blum, C.; Dalton, P.D.; Amsden, B.; Groll, J. Melt electrowriting below the critical translation speed to fabricate crimped elastomer scaffolds with non-linear extension behaviour mimicking that of ligaments and tendons. Acta Biomater. 2018, 72, 110-120. [CrossRef]

21. Gomes, M.E.; Azevedo, H.S.; Moreira, A.R.; Ellä, V.; Kellomäki, M.; Reis, R.L. Starch-poly(e-caprolactone) and starch-poly(lactic acid) fibre-mesh scaffolds for bone tissue engineering applications: Structure, mechanical properties and degradation behaviour. J. Tissue Eng. Regen. Med. 2008, 2, 243-252. [CrossRef]

22. Zhao, C.; Li, Y.; Peng, G.; Lei, X.; Zhang, G.; Gao, Y. Decellularized liver matrix-modified chitosan fibrous scaffold as a substrate for C3A hepatocyte culture. J. Biomater. Sci. Polym. Ed. 2020, 31, 1041-1056. [CrossRef]

23. Xie, M.; Wang, Z.; Wan, X.; Weng, J.; Tu, M.; Mei, J.; Wang, Z.; Du, X.; Wang, L.; Chen, C. Crosslinking effects of branched PEG on decellularized lungs of rats for tissue engineering. J. Biomater. Appl. 2019, 34, 965-974. [CrossRef] [PubMed]

24. Taylor, D.A.; Lee, P.-F.; Barac, Y.; Hochman-Mendez, C.; Sampaio, L.C. Decellularization of whole hearts for cardiac regeneration. Emerg. Technol. Heart Dis. 2020, 1, 291-310.

25. DeQuach, J.A.; Yuan, S.H.; Goldstein, L.S.B.; Christman, K.L. Decellularized Porcine Brain Matrix for Cell Culture and Tissue Engineering Scaffolds. Tissue Eng. Part A 2011, 17, 2583-2592. [CrossRef] [PubMed]

26. Seo, Y.; Jung, Y.; Kim, S.H. Decellularized heart ECM hydrogel using supercritical carbon dioxide for improved angiogenesis. Acta Biomater. 2018, 67, 270-281. [CrossRef]

27. Tomomi, G.; Otsuji, J.; Bin, A.; Yoshimura, M.; Tomura, D.; Tateyama, I.; Minami, Y.; Yoshikawa, K.; Aiba, J.E.; Heuser, T.; et al. A 3D Sphere Culture System Containing Functional Polymers for Large-Scale Human Pluripotent Stem Cell Production. Stem Cell Rep. 2014, 2, 734-745.

28. Howes, L.; Richardson, R.D.; Finlay, D.; Vuori, K. 3-Dimensional culture systems for anti-cancer compound profiling and high-throughput screening reveal increases in EGFR inhibitor-mediated cytotoxicity compared to monolayer culture systems. PLoS ONE 2014, 9, e108283. [CrossRef] [PubMed]

29. Cesarz, Z.; Tamama, K. Spheroid Culture of Mesenchymal Stem Cells. Stem Cells Int. 2016, 2016, 9176357. [CrossRef] [PubMed]

30. Ong, C.S.; Zhou, X.; Han, J.; Huang, C.Y.; Nashed, A.; Khatri, S.; Mattson, G.; Fukunishi, T.; Zhang, H.; Hibino, N. In vivo therapeutic applications of cell spheroids. Biotechnol. Adv. 2018, 36, 494-505. [CrossRef] [PubMed]

31. Daly, C.; Davidson, M.D.; Burdick, J.A. 3D bioprinting of high cell-density heterogeneous tissue models through spheroid fusion within self-healing hydrogels. Nat. Commun. 2021, 12, 753. [CrossRef]

32. Caló, E.; Khutoryanskiy, V.V. Biomedical applications of hydrogels: A review of patents and commercial products. Eur. Polym. J. 2015, 65, 252-267. [CrossRef]

33. Schmidt, J.J.; Rowley, J.; Kong, H.J. Hydrogels used for cell-based drug delivery. J. Biomed. Mater. Res. A 2008, 87, 1113-1122. [CrossRef]

34. Senol, S.; Akyol, E. Preparation and characterization of $\mathrm{pH}$-sensitive hydrogels from photo-crosslinked poly(ethylene glycol) diacrylate incorporating titanium dioxide. Mater. Sci. Pol. 2020, 38, 443-449.

35. Nam, S.; Stowers, R.; Lou, J.; Xia, Y.; Chaudhuri, O. Varying PEG density to control stress relaxation in alginate-PEG hydrogels for 3D cell culture studies. Biomaterials 2019, 200, 15-24. [CrossRef]

36. Lampe, K.J.; Mooney, R.G.; Bjugstad, K.B.; Mahoney, M.J. Effect of macromer weight percent on neural cell growth in 2D and 3D nondegradable PEG hydrogel culture. J. Biomed. Mater. Res. Part A 2010, 94A, 1162-1171. [CrossRef] [PubMed]

37. Zhao, Y.; Li, M.; Liu, B.; Xiang, J.; Cui, Z.; Qu, X.; Qiu, D.; Tian, Y.; Yang, Z. Ultra-tough injectable cytocompatible hydrogel for 3D cell culture and cartilage repair. J. Mater. Chem. B 2018, 6, 1351-1358. [CrossRef] [PubMed]

38. Muduli, S.; Chen, L.-H.; Li, M.-P.; Heish, Z.-w.; Liu, C.-H.; Kumar, S.; Alarfaj, A.A.; Munusamy, M.A.; Benelli, G.; Murugan, K.; et al. Stem cell culture on polyvinyl alcohol hydrogels having different elasticity and immobilized with ECM-derived oligopeptides. J. Polym. Eng. 2017, 37, 647-660. [CrossRef] 
39. Passos, M.F.; Carvalho, N.M.S.; Rodrigues, A.A.; Bavaresco, V.P.; Jardini, A.L.; Maciel, M.R.W.; Filho, R.M. PHEMA Hydrogels Obtained by Infrared Radiation for Cartilage Tissue Engineering. Int. J. Chem. Eng. 2019, 2019, 4249581. [CrossRef]

40. Mendez, U.; Zhou, H.; Shikanov, A. Synthetic PEG Hydrogel for Engineering the Environment of Ovarian Follicles. Methods Mol. Biol. 2018, 1758, 115-128.

41. Wang, D.; Yang, X.; Liu, Q.; Yu, L.; Ding, J. Enzymatically cross-linked hydrogels based on a linear poly(ethylene glycol) analogue for controlled protein release and 3D cell culture. J. Mater. Chem. B 2018, 6, 6067-6079. [CrossRef]

42. Andrée, B.; Ichanti, H.; Kalies, S.; Heisterkamp, A.; Strauß, S.; Vogt, P.-M.; Haverich, A.; Hilfiker, A. Formation of threedimensional tubular endothelial cell networks under defined serum-free cell culture conditions in human collagen hydrogels. Sci. Rep. 2019, 9, 5437. [CrossRef]

43. Hached, F.; Vinatier, C.; Pinta, P.-G.; Hulin, P.; le Visage, C.; Weiss, P.; Guicheux, J.; Billon-Chabaud, A.; Grimandi, G. Polysaccharide Hydrogels Support the Long-Term Viability of Encapsulated Human Mesenchymal Stem Cells and Their Ability to Secrete Immunomodulatory Factors. Stem Cells Int. 2017, 2017, 9303598. [CrossRef]

44. Frampton, J.P.; Hynd, M.R.; Shuler, M.L.; Shain, W. Fabrication and optimization of alginate hydrogel constructs for use in 3D neural cell culture. Biomed. Mater. 2011, 6, 015002. [CrossRef] [PubMed]

45. Wu, S.; Xu, R.; Duan, B.; Jiang, P. Three-dimensional hyaluronic acid hydrogel-based models for in vitro human iPSC-derived NPC culture and differentiation. J. Mater. Chem. B 2017, 5, 3870-3878. [CrossRef] [PubMed]

46. Suo, A.; Xu, W.; Wang, Y.; Sun, T.; Ji, L.; Qian, J. Dual-degradable and injectable hyaluronic acid hydrogel mimicking extracellular matrix for 3D culture of breast cancer MCF-7 cells. Carbohydr. Polym. 2019, 211, 336-348. [CrossRef] [PubMed]

47. Bao, Z.; Xian, C.; Yuan, Q.; Liu, G.; Wu, J. Natural Polymer-Based Hydrogels with Enhanced Mechanical Performances: Preparation, Structure, and Property. Adv. Healthc. Mater. 2019, 8, 1900670. [CrossRef]

48. Lee, Y.-B.; Polio, S.; Lee, W.; Dai, G.; Menon, L.; Carroll, R.S.; Yoo, S.-S. Bio-printing of collagen and VEGF-releasing fibrin gel scaffolds for neural stem cell culture. Exp. Neurol. 2010, 223, 645-652. [CrossRef]

49. Lou, J.; Stowers, R.; Nam, S.; Xia, Y.; Chaudhuri, O. Stress relaxing hyaluronic acid-collagen hydrogels promote cell spreading, fiber remodeling, and focal adhesion formation in 3D cell culture. Biomaterials 2018, 154, 213-222. [CrossRef]

50. Park, S.H.; Kim, K.; Lim, J.H.; Lee, S.J. Selective lithium and magnesium adsorption by phosphonate metal-organic frameworkincorporated alginate hydrogel inspired from lithium adsorption characteristics of brown algae. Sep. Purif. Technol. 2019, 212, 611-618. [CrossRef]

51. Ullah, F.; Javed, F.; Zakaria, M.R.; Jamila, D.N.; Khattak, R.; Khan, A.; Akil, H.M. Determining the Molecular-weight and interfacial properties of chitosan built nanohydrogel for controlled drug delivery applications. Biointerface Res. Appl. Chem. 2019, $9,4452-4457$.

52. Ullah, F.; Javed, F.; Khan, A.; Kudus, M.; Jamila, N.; Minhaz, A.; Akil, H. Synthesis and surface modification of chitosan built nanohydrogel with antiviral and antimicrobial agent for controlled drug delivery. Biointerface Res. Appl. Chem. 2019, 9, 4439-4445.

53. Kim, J.-S.; Kim, T.H.; Kang, D.L.; Baek, S.Y.; Lee, Y.; Koh, Y.-G.; Kim, Y.I. Chondrogenic differentiation of human ASCs by stiffness control in 3D fibrin hydrogel. Biochem. Biophys. Res. Commun. 2020, 522, 213-219. [CrossRef] [PubMed]

54. Faraj, K.A.; van Kuppevelt, T.H.; Daamen, W.F. Construction of Collagen Scaffolds That Mimic the Three-Dimensional Architecture of Specific Tissues. Tissue Eng. 2007, 13, 2387-2394. [CrossRef] [PubMed]

55. Cui, Z.-K.; Li, S.-Y.; Liao, K.; Wang, Z.-J.; Guo, Y.-L.; Tang, L.-S.; Tang, S.-B.; Ma, J.; Chen, J.-S. Characteristics of neural growth and cryopreservation of the dorsal root ganglion using three-dimensional collagen hydrogel culture vs. conventional culture. Neural Regen. Res. 2021, 16, 1856-1864.

56. Smeriglio, P.; Dhulipala, L.; Lai, J.H.; Goodman, S.B.; Dragoo, J.L.; Smith, R.L.; Maloney, W.J.; Yang, F.; Bhutani, N. Collagen VI Enhances Cartilage Tissue Generation by Stimulating Chondrocyte Proliferation. Tissue Eng. Part A 2014, 21, 840-849. [CrossRef] [PubMed]

57. Pachence, J.M. Collagen-based devices for soft tissue repair. J. Biomed. Mater. Res. 1996, 33, 35-40. [CrossRef]

58. Benea, H.; Tomoaia, G.; Soritau, O.; Pasca, R.D. A Review on the Reconstruction of Articular Cartilage Using Collagen Scaffolds. Rom. Biotechnol. Lett. 2016, 21, 11735-11743.

59. Jin, G.-Z.; Kim, H.-W. Effects of Type I Collagen Concentration in Hydrogel on the Growth and Phenotypic Expression of Rat Chondrocytes. Tissue Eng. Regen. Med. 2017, 14, 383-391. [CrossRef]

60. Tamaddon, M.; Burrows, M.; Ferreira, S.A.; Dazzi, F.; Apperley, J.F.; Bradshaw, A.; Brand, D.D.; Czernuszka, J.; Gentleman, E. Monomeric, porous type II collagen scaffolds promote chondrogenic differentiation of human bone marrow mesenchymal stem cells in vitro. Sci. Rep. 2017, 7, 43519. [CrossRef]

61. Kilmer, C.E.; Battistoni, C.M.; Cox, A.; Breur, G.J.; Panitch, A.; Liu, J.C. Collagen Type I and II Blend Hydrogel with Autologous Mesenchymal Stem Cells as a Scaffold for Articular Cartilage Defect Repair. Acs Biomater. Sci. Eng. 2020, 6, 3464-3476. [CrossRef]

62. Irawan, V.; Sung, T.-C.; Higuchi, A.; Ikoma, T. Collagen Scaffolds in Cartilage Tissue Engineering and Relevant Approaches for Future Development. Tissue Eng. Regen. Med. 2018, 15, 673-697. [CrossRef]

63. Perez-Puyana, V.; Romero, A.; Guerrero, A. Influence of collagen concentration and glutaraldehyde on collagen-based scaffold properties. J. Biomed. Mater. Res. Part A 2016, 104, 1462-1468. [CrossRef]

64. Nong, L.-M.; Zhou, D.; Zheng, D.; Jiang, Y.-Q.; Xu, N.-W.; Zhao, G.-Y.; Wei, H.; Zhou, S.-Y.; Han, H.; Han, L. The effect of different cross-linking conditions of EDC/NHS on type II collagen scaffolds: An in vitro evaluation. Cell Tissue Bank. 2019, 20, 557-568. [CrossRef] [PubMed] 
65. Lotz, C.; Schmid, F.F.; Oechsle, E.; Monaghan, M.G.; Walles, H.; Groeber-Becker, F. Cross-linked Collagen Hydrogel Matrix Resisting Contraction To Facilitate Full-Thickness Skin Equivalents. Acs Appl. Mater. Interfaces 2017, 9, 20417-20425. [CrossRef] [PubMed]

66. Li, H.; Koenig, A.M.; Sloan, P.; Leipzig, N.D. In vivo assessment of guided neural stem cell differentiation in growth factor immobilized chitosan-based hydrogel scaffolds. Biomaterials 2014, 35, 9049-9057. [CrossRef]

67. Sun, Y.; Yang, C.; Zhu, X.; Wang, J.-J.; Liu, X.-Y.; Yang, X.-P.; An, X.-W.; Liang, J.; Dong, H.-J.; Jiang, W.; et al. 3D printing collagen/chitosan scaffold ameliorated axon regeneration and neurological recovery after spinal cord injury. J. Biomed. Mater. Res. Part A 2019, 107, 1898-1908. [CrossRef] [PubMed]

68. Ying, H.; Zhou, J.; Wang, M.; Su, D.; Ma, Q.; Lv, G.; Chen, J. In situ formed collagen-hyaluronic acid hydrogel as biomimetic dressing for promoting spontaneous wound healing. Mater. Sci. Eng. C 2019, 101, 487-498. [CrossRef]

69. Kolodney, M.S.; Wysolmerski, R.B. Isometric contraction by fibroblasts and endothelial cells in tissue culture: A quantitative study. J. Cell Biol. 1992, 117, 73-82. [CrossRef]

70. Price, R.D.; Berry, M.G.; Navsaria, H.A. Hyaluronic acid: The scientific and clinical evidence. J. Plast. Reconstr. Aesthetic Surg. 2007, 60, 1110-1119. [CrossRef]

71. Liu, L.; Liu, Y.; Li, J.; Du, G.; Chen, J. Microbial production of hyaluronic acid: Current state, challenges, and perspectives. Microb. Cell Factories 2011, 10, 99. [CrossRef]

72. Lei, Y.; Gojgini, S.; Lam, J.; Segura, T. The spreading, migration and proliferation of mouse mesenchymal stem cells cultured inside hyaluronic acid hydrogels. Biomaterials 2011, 32, 39-47. [CrossRef] [PubMed]

73. Seidlits, S.K.; Khaing, Z.Z.; Petersen, R.R.; Nickels, J.D.; Vanscoy, J.E.; Shear, J.B.; Schmidt, C.E. The effects of hyaluronic acid hydrogels with tunable mechanical properties on neural progenitor cell differentiation. Biomaterials 2010, 31, 3930-3940. [CrossRef]

74. Inoue, M.; Katakami, C. The effect of hyaluronic acid on corneal epithelial cell proliferation. Investig. Ophthalmol. Vis. Sci. 1993, 34, 2313-2315.

75. Chen, J.-W.E.; Pedron, S.; Shyu, P.; Hu, Y.; Sarkaria, J.N.; Harley, B.A.C. Influence of Hyaluronic Acid Transitions in Tumor Microenvironment on Glioblastoma Malignancy and Invasive Behavior. Front. Mater. 2018, 5, 39. [CrossRef] [PubMed]

76. Boregowda, R.K.; Appaiah, H.N.; Siddaiah, M.; Kumarswamy, S.B.; Sunila, S.; Thimmaiah, K.N.; Mortha, K.; Toole, B.; Banerjee, S.D. Expression of hyaluronan in human tumor progression. J. Carcinog. 2006, 5, 2. [CrossRef]

77. Assmann, V.; Fieber, C.; Herrlich, P.; Hofmann, M.; Termeer, C.C.; Ahrens, T.; Simon, J.C. CD44 is the Principal Mediator of Hyaluronic-Acid-Induced Melanoma Cell Proliferation. J. Investig. Dermatol. 2001, 116, 93-101. [CrossRef]

78. Bucatariu, S.-M.; Constantin, M.; Varganici, C.-D.; Rusu, D.; Nicolescu, A.; Prisacaru, I.; Carnuta, M.; Anghelache, M.; Calin, M.; Ascenzi, P.; et al. A new sponge-type hydrogel based on hyaluronic acid and poly(methylvinylether-alt-maleic acid) as a 3D platform for tumor cell growth. Int. J. Biol. Macromol. 2020, 165, 2528-2540. [CrossRef]

79. Häckel, S.; Zolfaghar, M.; Du, J.; Hoppe, S.; Benneker, L.M.; Garstka, N.; Peroglio, M.; Alini, M.; Grad, S.; Yayon, A.; et al Fibrin-Hyaluronic Acid Hydrogel (RegenoGel) with Fibroblast Growth Factor-18 for In Vitro 3D Culture of Human and Bovine Nucleus Pulposus Cells. Int. J. Mol. Sci. 2019, 20, 5036. [CrossRef]

80. Lee, E.J.; Kang, E.; Kang, S.-W.; Huh, K.M. Thermo-irreversible glycol chitosan/hyaluronic acid blend hydrogel for injectable tissue engineering. Carbohydr. Polym. 2020, 244, 116432. [CrossRef]

81. Ning, L.; Zhu, N.; Mohabatpour, F.; Sarker, M.D.; Schreyer, D.J.; Chen, X. Bioprinting Schwann cell-laden scaffolds from low-viscosity hydrogel compositions. J. Mater. Chem. B 2019, 7, 4538-4551. [CrossRef]

82. Lee, K.Y.; Mooney, D.J. Alginate: Properties and biomedical applications. Prog. Polym. Sci. 2012, 37, 106-126. [CrossRef]

83. Lee, K.Y.; Mooney, D.J. Hydrogels for Tissue Engineering. Chem. Rev. 2001, 101, 1869-1880. [CrossRef] [PubMed]

84. Chaudhuri, O.; Gu, L.; Klumpers, D.; Darnell, M.; Bencherif, S.A.; Weaver, J.C.; Huebsch, N.; Lee, H.-P.; Lippens, E.; Duda, G.N.; et al. Hydrogels with tunable stress relaxation regulate stem cell fate and activity. Nat. Mater. 2016, 15, 326-334. [CrossRef] [PubMed]

85. Huebsch, N.; Arany, P.R.; Mao, A.S.; Shvartsman, D.; Ali, O.A.; Bencherif, S.A.; Rivera-Feliciano, J.; Mooney, D.J. Harnessing traction-mediated manipulation of the cell/matrix interface to control stem-cell fate. Nat. Mater. 2010, 9, 518-526. [CrossRef]

86. Nakamura, M.; Iwanaga, S.; Henmi, C.; Arai, K.; Nishiyama, Y. Biomatrices and biomaterials for future developments of bioprinting and biofabrication. Biofabrication 2010, 2, 014110. [CrossRef] [PubMed]

87. Gao, T.; Gillispie, G.J.; Copus, J.S.; Pr, A.K.; Seol, Y.-J.; Atala, A.; Yoo, J.J.; Lee, S.J. Optimization of gelatin-alginate composite bioink printability using rheological parameters: A systematic approach. Biofabrication 2018, 10, 034106. [CrossRef] [PubMed]

88. Jia, J.; Richards, D.J.; Pollard, S.; Tan, Y.; Rodriguez, J.; Visconti, R.P.; Trusk, T.C.; Yost, M.J.; Yao, H.; Markwald, R.R.; et al. Engineering alginate as bioink for bioprinting. Acta Biomater. 2014, 10, 4323-4331. [CrossRef]

89. Alagpulinsa, D.A.; Cao, J.J.L.; Driscoll, R.K.; Sîrbulescu, R.F.; Penson, M.F.E.; Sremac, M.; Engquist, E.N.; Brauns, T.A.; Markmann, J.F.; Melton, D.A.; et al. Alginate-microencapsulation of human stem cell-derived $\beta$ cells with CXCL12 prolongs their survival and function in immunocompetent mice without systemic immunosuppression. Am. J. Transplant. 2019, 19, $1930-1940$.

90. De Vos, P.; Faas, M.M.; Strand, B.; Calafiore, R. Alginate-based microcapsules for immunoisolation of pancreatic islets. Biomaterials 2006, 27, 5603-5617. [CrossRef] 
91. Stock, A.; Manzoli, V.; de Toni, T.; Abreu, M.M.; Poh, Y.-C.; Ye, L.; Roose, A.; Pagliuca, F.W.; Thanos, C.; Ricordi, C.; et al. Conformal Coating of Stem Cell-Derived Islets for $\beta$ Cell Replacement in Type 1 Diabetes. Stem Cell Rep. 2020, 14, 91-104. [CrossRef] [PubMed]

92. Cheng, K.; Kisaalita, W.S. Exploring cellular adhesion and differentiation in a micro-/nano-hybrid polymer scaffold. Biotechnol. Prog. 2010, 26, 838-846. [CrossRef] [PubMed]

93. Weigel, T.; Schinkel, G.; Lendlein, A. Design and preparation of polymeric scaffolds for tissue engineering. Expert Rev. Med Devices 2006, 3, 835-851. [CrossRef]

94. Mondal, S.; Nguyen, T.P.; Pham, V.H.; Hoang, G.; Manivasagan, P.; Kim, M.H.; Nam, S.Y.; Oh, J. Hydroxyapatite nano bioceramics optimized 3D printed poly lactic acid scaffold for bone tissue engineering application. Ceram. Int. 2020, 46, 3443-3455. [CrossRef]

95. Eslami, H.; Lisar, H.A.; Kashi, T.S.J.; Tahriri, M.; Ansari, M.; Rafiei, T.; Bastami, F.; Shahin-Shamsabadi, A.; Abbas, F.M.; Tayebi, L. Poly(lactic-co-glycolic acid)(PLGA)/TiO2 nanotube bioactive composite as a novel scaffold for bone tissue engineering: In vitro and in vivo studies. Biologicals 2018, 53, 51-62. [CrossRef]

96. Le, C.M.T.; Monajjemi, M.; Mollaamin, F.; Dang, C. Simulation \& modelling of dilute solutions in drop-on-demand inkjet printing: A review. Biointerface Res. Appl. Chem. 2019, 9, 4474-4484.

97. Trakoolwannachai, V.; Kheolamai, P.; Ummartyotin, S. Characterization of hydroxyapatite from eggshell waste and polycaprolactone (PCL) composite for scaffold material. Compos. Part B: Eng. 2019, 173, 106974. [CrossRef]

98. Bagheri-Hosseinabadi, Z.; Mesbah-Namin, S.A.; Salehinejad, P.; Seyedi, F. Fibrin scaffold could promote survival of the human adipose-derived stem cells during differentiation into cardiomyocyte-like cells. Cell Tissue Res. 2018, 372, 571-589. [CrossRef]

99. Yan, R.; Chen, Y.; Gu, Y.; Tang, C.; Huang, J.; Hu, Y.; Zheng, Z.; Ran, J.; Heng, B.; Chen, X.; et al. A collagen-coated sponge silk scaffold for functional meniscus regeneration. J. Tissue Eng. Regen. Med. 2019, 13, 156-173. [CrossRef]

100. Thadavirul, N.; Pavasant, P.; Supaphol, P. Development of polycaprolactone porous scaffolds by combining solvent casting, particulate leaching, and polymer leaching techniques for bone tissue engineering. J. Biomed. Mater. Res. Part A 2014, 102, 3379-3392. [CrossRef]

101. Sin, D.; Miao, X.; Liu, G.; Wei, F.; Chadwick, G.; Yan, C.; Friis, T. Polyurethane (PU) scaffolds prepared by solvent casting/particulate leaching (SCPL) combined with centrifugation. Mater. Sci. Eng. 2010, 30, 78-85. [CrossRef]

102. Zhou, S.; Bismarck, A.; Steinke, J.H.G. Ion-responsive alginate based macroporous injectable hydrogel scaffolds prepared by emulsion templating. J. Mater. Chem. B 2013, 1, 4736-4745. [CrossRef] [PubMed]

103. Yadav, A.; Pal, J.; Nandan, B.; Srivastava, R.K. Macroporous scaffolds of cross-linked Poly( $\varepsilon$-caprolactone) via high internal phase emulsion templating. Polymer 2019, 176, 66-73. [CrossRef]

104. Salerno, A.; Oliviero, M.; Di Maio, E.; Iannace, S.; Netti, P.A. Design of porous polymeric scaffolds by gas foaming of heterogeneous blends. J. Mater. Sci. 2009, 20, 2043-2051. [CrossRef]

105. Bak, T.-Y.; Kook, M.-S.; Jung, S.-C.; Kim, B.-H. Biological Effect of Gas Plasma Treatment on $\mathrm{CO}_{2}$ Gas Foaming/Salt Leaching Fabricated Porous Polycaprolactone Scaffolds in Bone Tissue Engineering. J. Nanomater. 2014, 2014, 657542. [CrossRef]

106. Ji, C.; Annabi, N.; Khademhosseini, A.; Dehghani, F. Fabrication of porous chitosan scaffolds for soft tissue engineering using dense gas $\mathrm{CO}_{2}$. Acta Biomater. 2011, 7, 1653-1664. [CrossRef] [PubMed]

107. Gomes, M.E.; Ribeiro, A.S.; Malafaya, P.B.; Reis, R.L.; Cunha, A.M. A new approach based on injection moulding to produce biodegradable starch-based polymeric scaffolds: Morphology, mechanical and degradation behaviour. Biomaterials 2001, 22, 883-889. [CrossRef]

108. El-Ayoubi, R.; Eliopoulos, N.; Diraddo, R.; Galipeau, J.; Yousefi, A.-M. Design and Fabrication of 3D Porous Scaffolds to Facilitate Cell-Based Gene Therapy. Tissue Eng. Part A 2008, 14, 1037-1048. [CrossRef]

109. Bonfield, W. Designing porous scaffolds for tissue engineering. Philos. Trans. R. Soc. A Math. Phys. Eng. Sci. 2006, 364, 227-232. [CrossRef]

110. Prasad, M.; Sankar, R.; Katiyar, V. State of Art on Solvent Casting Particulate Leaching Method for Orthopedic ScaffoldsFabrication. Mater. Today 2017, 4, 898-907. [CrossRef]

111. Deng, Y.; Zhang, M.; Chen, X.; Pu, X.; Liao, X.; Huang, Z.; Yin, G. A novel akermanite/poly (lactic-co-glycolic acid) porous composite scaffold fabricated via a solvent casting-particulate leaching method improved by solvent self-proliferating process. Regen. Biomater. 2017, 4, 233-242. [CrossRef]

112. Xiao, Y.; Zhou, M.; Zhang, M.; Liu, W.; Zhou, Y.; Lang, M. Hepatocyte culture on 3D porous scaffolds of PCL/PMCL. Colloids Surf. $B$ 2019, 173, 185-193. [CrossRef] [PubMed]

113. Shim, J.-H.; Kim, A.J.; Park, J.Y.; Yi, N.; Kang, I.; Park, J.; Rhie, J.-W.; Cho, D.-W. Effect of solid freeform fabrication-based polycaprolactone/poly(lactic-co-glycolic acid)/collagen scaffolds on cellular activities of human adipose-derived stem cells and rat primary hepatocytes. J. Mater. Sci. 2013, 24, 1053-1065.

114. Riesco, R.; Boyer, L.; Blosse, S.; Lefebvre, P.M.; Assemat, P.; Leichle, T.; Accardo, A.; Malaquin, L. Water-in-PDMS Emulsion Templating of Highly Interconnected Porous Architectures for 3D Cell Culture. Acs Appl. Mater. Interfaces 2019, 11, 28631-28640. [CrossRef]

115. Wu, S.; Liu, X.; Yeung, K.W.K.; Liu, C.; Yang, X. Biomimetic porous scaffolds for bone tissue engineering. Mater. Sci. Eng. 2014, 80, 1-36. [CrossRef]

116. Lemon, G.; Waters, S.L.; Rose, F.R.A.J.; King, J.R. Mathematical modelling of human mesenchymal stem cell proliferation and differentiation inside artificial porous scaffolds. J. Theor. Biol. 2007, 249, 543-553. [CrossRef] [PubMed] 
117. Zhang, M.; Boughton, P.; Rose, B.; Lee, C.S.; Hong, A.M. The Use of Porous Scaffold as a Tumor Model. Int. J. Biomater. 2013, 2013, 396056. [CrossRef] [PubMed]

118. Dar, A.; Shachar, M.; Leor, J.; Cohen, S. Optimization of cardiac cell seeding and distribution in 3D porous alginate scaffolds. Biotechnol. Bioeng. 2002, 80, 305-312. [CrossRef] [PubMed]

119. Ardila, D.C.; Tamimi, E.; Doetschman, T.; Wagner, W.R.; Geest, J.P.V. Modulating smooth muscle cell response by the release of TGF 32 from tubular scaffolds for vascular tissue engineering. J. Control. Release 2019, 299, 44-52. [CrossRef] [PubMed]

120. Ren, T.; Ren, J.; Jia, X.; Pan, K. The bone formation in vitro and mandibular defect repair using PLGA porous scaffolds. J. Biomed. Mater. Res. Part A 2005, 74A, 562-569. [CrossRef]

121. Chang, N.J.; Lam, C.F.; Lin, C.C.; Chen, W.L.; Li, C.F.; Lin, Y.T.; Yeh, M.L. Transplantation of autologous endothelial progenitor cells in porous PLGA scaffolds create a microenvironment for the regeneration of hyaline cartilage in rabbits. Osteoarthr. Cartil. 2013, 21, 1613-1622. [CrossRef] [PubMed]

122. Bloise, N.; Berardi, E.; Gualandi, C.; Zaghi, E.; Gigli, M.; Duelen, R.; Ceccarelli, G.; Cortesi, E.E.; Costamagna, D.; Bruni, G.; et al. Ether-Oxygen Containing Electrospun Microfibrous and Sub-Microfibrous Scaffolds Based on Poly(butylene 1,4cyclohexanedicarboxylate) for Skeletal Muscle Tissue Engineering. Int. J. Mol. Sci. 2018, 19, 3212. [CrossRef]

123. MacQueen, L.A.; Alver, C.G.; Chantre, C.O.; Ahn, S.; Cera, L.; Gonzalez, G.M.; O'Connor, B.B.; Drennan, D.J.; Peters, M.M.; Motta, S.E.; et al. Muscle tissue engineering in fibrous gelatin: Implications for meat analogs. NPJ Sci. Food 2019, 3, 20. [CrossRef]

124. Jang, S.R.; Kim, J.I.; Park, C.H.; Kim, C.S. The controlled design of electrospun PCL/silk/quercetin fibrous tubular scaffold using a modified wound coil collector and L-shaped ground design for neural repair. Mater. Sci. Eng. C 2020, 111, 110776. [CrossRef]

125. Liu, H.; Wang, Y.; Yang, Y.; Wang, A.; Huang, C.; Zhao, Z.; Li, P.; Liu, M.; Fan, Y. Aligned graphene/silk fibroin conductive fibrous scaffolds for guiding neurite outgrowth in rat spinal cord neurons. J. Biomed. Mater. Res. Part A 2020. [CrossRef] [PubMed]

126. Joshi, J.; Brennan, D.; Beachley, V.; Kothapalli, C.R. Cardiomyogenic differentiation of human bone marrow-derived mesenchymal stem cell spheroids within electrospun collagen nanofiber mats. J. Biomed. Mater. Res. Part A 2018, 106, 3303-3312. [CrossRef] [PubMed]

127. Damaraju, S.M.; Shen, Y.; Elele, E.; Khusid, B.; Eshghinejad, A.; Li, J.; Jaffe, M.; Arinzeh, T.L. Three-dimensional piezoelectric fibrous scaffolds selectively promote mesenchymal stem cell differentiation. Biomaterials 2017, 149, 51-62. [CrossRef] [PubMed]

128. Rahmani, A.; Nadri, S.; Kazemi, H.S.; Mortazavi, Y.; Sojoodi, M. Conductive electrospun scaffolds with electrical stimulation for neural differentiation of conjunctiva mesenchymal stem cells. Artif. Organs 2019, 43, 780-790. [CrossRef] [PubMed]

129. Brennan, M.; Eichholz, K.F.; Hoey, D.A. The effect of pore size within fibrous scaffolds fabricated using melt electrowriting on human bone marrow stem cell osteogenesis. Biomed. Mater. 2019, 14, 065016. [CrossRef]

130. Birhanu, G.; Javar, H.A.; Seyedjafari, E.; Zandi-Karimi, A.; Telgerd, M.D. An improved surface for enhanced stem cell proliferation and osteogenic differentiation using electrospun composite PLLA/P123 scaffold. Artif. CellsNanomed. Biotechnol. 2018, 46, 1274-1281. [CrossRef]

131. Boland, E.D.; Wnek, G.E.; Simpson, D.G.; Pawlowski, K.J.; Bowlin, G.L. Tailoring tissue engineering scaffolds using electrostatic processing techniques: A study of poly(glycolic acid) electrospinning. J. Macromol. Sci. Part A 2001, 38, 1231-1243. [CrossRef]

132. Eberli, D.; Filho, L.F.; Atala, A.; Yoo, J.J. Composite scaffolds for the engineering of hollow organs and tissues. Methods 2009, 47, 109-115. [CrossRef]

133. Sartuqui, J.; D’Elía, N.L.; Ercoli, D.; de Alcazar, D.S.; Cortajarena, A.L.; Messina, P.V. Mechanical performance of gelatin fiber mesh scaffolds reinforced with nano-hydroxyapatite under bone damage mechanisms. Mater. Today Commun. 2019, 19, 140-147. [CrossRef]

134. Lee, S.J.; Oh, S.H.; Liu, J.; Soker, S.; Atala, A.; Yoo, J.J. The use of thermal treatments to enhance the mechanical properties of electrospun poly( $\varepsilon$-caprolactone) scaffolds. Biomaterials 2008, 29, 1422-1430. [CrossRef] [PubMed]

135. Hosseini, V.; Evrova, O.; Hoerstrup, S.P.; Vogel, V. A Simple Modification Method to Obtain Anisotropic and Porous 3D Microfibrillar Scaffolds for Surgical and Biomedical Applications. Small 2018, 14, 1702650. [CrossRef]

136. Lee, S.; Nagata, F.; Kato, K.; Nakano, T. Bone apatite anisotropic structure control via designing fibrous scaffolds. RSC Adv. 2020, 10, 13500-13506. [CrossRef]

137. Nam, Y.S.; Park, T.G. Porous biodegradable polymeric scaffolds prepared by thermally induced phase separation. J. Biomed. Mater. Res. 1999, 47, 8-17. [CrossRef]

138. Tu, C.; Cai, Q.; Yang, J.; Wan, Y.; Bei, J.; Wang, S. The fabrication and characterization of poly(lactic acid) scaffolds for tissue engineering by improved solid-liquid phase separation. Polym. Adv. Technol. 2003, 14, 565-573. [CrossRef]

139. Zhang, S.; Gelain, F.; Zhao, X. Designer self-assembling peptide nanofiber scaffolds for 3D tissue cell cultures. Semin. Cancer Biol. 2005, 15, 413-420. [CrossRef] [PubMed]

140. Chen, W.; Ma, J.; Zhu, L.; Morsi, Y.; Ei-Hamshary, H.; Al-Deyab, S.S.; Mo, X. Superelastic, superabsorbent and 3D nanofiberassembled scaffold for tissue engineering. Colloids Surf. B 2016, 142, 165-172. [CrossRef]

141. Wang, S.; Nagrath, D.; Chen, P.C.; Berthiaume, F.; Yarmush, M.L. Three-Dimensional Primary Hepatocyte Culture in Synthetic Self-Assembling Peptide Hydrogel. Tissue Eng. Part A 2008, 14, 227-236. [CrossRef]

142. Galler, K.M.; Cavender, A.; Yuwono, V.; Dong, H.; Shi, S.; Schmalz, G.; Hartgerink, J.D.; D’Souza, R.N. Self-Assembling Peptide Amphiphile Nanofibers as a Scaffold for Dental Stem Cells. Tissue Eng. Part A 2008, 14, 2051-2058. [CrossRef] [PubMed]

143. Thorvaldsson, A.; Stenhamre, H.; Gatenholm, P.; Walkenström, P. Electrospinning of Highly Porous Scaffolds for Cartilage Regeneration. Biomacromolecules 2008, 9, 1044-1049. [CrossRef] [PubMed] 
144. Zhang, Y.; Ouyang, H.; Lim, C.T.; Ramakrishna, S.; Huang, Z.-M. Electrospinning of gelatin fibers and gelatin/PCL composite fibrous scaffolds. J. Biomed. Mater. Res. Part B 2005, 72B, 156-165. [CrossRef]

145. Lannutti, J.; Reneker, D.; Ma, T.; Tomasko, D.; Farson, D. Electrospinning for tissue engineering scaffolds. Mater. Sci. Eng. C 2007, 27, 504-509. [CrossRef]

146. Cai, Q.; Yang, J.; Bei, J.; Wang, S. A novel porous cells scaffold made of polylactide-dextran blend by combining phase-separation and particle-leaching techniques. Biomaterials 2002, 23, 4483-4492. [CrossRef]

147. Blum, S.; Soto, C.M.; Wilson, C.D.; Brower, T.L.; Pollack, S.K.; Schull, T.L.; Chatterji, A.; Lin, T.; Johnson, J.E.; Amsinck, C.; et al. An Engineered Virus as a Scaffold for Three-Dimensional Self-Assembly on the Nanoscale. Small 2005, 1, 702-706. [CrossRef]

148. Liu, Y.; Wang, S.; Lee, J.W.; Kotov, N.A. A Floating Self-Assembly Route to Colloidal Crystal Templates for 3D Cell Scaffolds. Chem. Mater. 2005, 17, 4918-4924. [CrossRef]

149. Zhang, X.; Morits, M.; Jonkergouw, C.; Ora, A.; Valle-Delgado, J.J.; Farooq, M.; Ajdary, R.; Huan, S.; Linder, M.; Rojas, O.; et al. Three-Dimensional Printed Cell Culture Model Based on Spherical Colloidal Lignin Particles and Cellulose Nanofibril-Alginate Hydrogel. Biomacromolecules 2020, 21, 1875-1885. [CrossRef]

150. Sasayama, S.; Hara, T.; Tanaka, T.; Honda, Y.; Baba, S. Osteogenesis of Multipotent Progenitor Cells using the Epigallocatechin Gallate-Modified Gelatin Sponge Scaffold in the Rat Congenital Cleft-Jaw Model. Int. J. Mol. Sci. 2018, 19, 3803. [CrossRef]

151. Dong, L.; Wang, S.J.; Zhao, X.R.; Zhu, Y.F.; Yu, J.K. 3D- Printed Poly(epsilon-caprolactone) Scaffold Integrated with Cell-laden Chitosan Hydrogels for Bone Tissue Engineering. Sci. Rep. 2017, 7, 13412. [CrossRef]

152. Guyette, J.P.; Gilpin, S.E.; Charest, J.M.; Tapias, L.F.; Ren, X.; Ott, H.C. Perfusion decellularization of whole organs. Nat. Protoc. 2014, 9, 1451-1468. [CrossRef] [PubMed]

153. Daryabari, S.S.; Kajbafzadeh, A.-M.; Fendereski, K.; Ghorbani, F.; Dehnavi, M.; Rostami, M.; Garajegayeh, B.A.; Tavangar, S.M. Development of an efficient perfusion-based protocol for whole-organ decellularization of the ovine uterus as a human-sized model and in vivo application of the bioscaffolds. J. Assist. Reprod. Genet. 2019, 36, 1211-1223. [CrossRef] [PubMed]

154. Krishtul, S.; Baruch, L.; Machluf, M. Processed Tissue-Derived Extracellular Matrices: Tailored Platforms Empowering Diverse Therapeutic Applications. Adv. Funct. Mater. 2020, 30, 1900386. [CrossRef]

155. Sierad, L.N.; Shaw, E.L.; Bina, A.; Brazile, B.; Rierson, N.; Patnaik, S.S.; Kennamer, A.; Odum, R.; Cotoi, O.; Terezia, P.; et al Functional Heart Valve Scaffolds Obtained by Complete Decellularization of Porcine Aortic Roots in a Novel Differential Pressure Gradient Perfusion System. Tissue Eng. Part C 2015, 21, 1284-1296. [CrossRef] [PubMed]

156. Syed, O.; Walters, N.J.; Day, R.M.; Kim, H.-W.; Knowles, J.C. Evaluation of decellularization protocols for production of tubular small intestine submucosa scaffolds for use in oesophageal tissue engineering. Acta Biomater. 2014, 10, 5043-5054. [CrossRef] [PubMed]

157. Casali, D.M.; Handleton, R.M.; Shazly, T.; Matthews, M.A. A novel supercritical CO2-based decellularization method for maintaining scaffold hydration and mechanical properties. J. Supercrit. Fluids 2018, 131, 72-81. [CrossRef]

158. David, M.S.; Saubaméa, B.; Susen, S.; Kindo, M.; Bruneval, P.; van Belle, E.; Jansen, P.; Roussel, J.-C.; Latrémouille, C.; Carpentier, A. Bioprosthetic Total Artificial Heart Induces a Profile of Acquired Hemocompatibility with Membranes Recellularization. J. Am. Coll. Cardiol. 2017, 70, 404-406.

159. Tsuchiya, T.; Sivarapatna, A.; Rocco, K.; Nanashima, A.; Nagayasu, T.; Niklason, L.E. Future prospects for tissue engineered lung transplantation. Organogenesis 2014, 10, 196-207. [CrossRef]

160. Caires-Júnior, L.C.; Goulart, E.; Telles-Silva, K.A.; Araujo, B.H.S.; Musso, C.M.; Kobayashi, G.; Oliveira, D.; Assoni, A.; Carvalho, V.M.; Ribeiro, A.F., Jr.; et al. Pre-coating decellularized liver with HepG2-conditioned medium improves hepatic recellularization. Mater. Sci. Eng. C 2021, 121, 111862. [CrossRef]

161. Soto-Gutierrez, A.; Zhang, L.; Medberry, C.; Fukumitsu, K.; Faulk, D.; Jiang, H.; Reing, J.; Gramignoli, R.; Komori, J.; Ross, M.; et al. A Whole-Organ Regenerative Medicine Approach for Liver Replacement. Tissue Eng. Part C 2011, 17, 677-686. [CrossRef] [PubMed]

162. Hillebrandt, K.H.; Everwien, H.; Haep, N.; Keshi, E.; Pratschke, J.; Sauer, I.M. Strategies based on organ decellularization and recellularization. Transpl. Int. 2019, 32, 571-585. [CrossRef]

163. Shimoda, H.; Yagi, H.; Higashi, H.; Tajima, K.; Kuroda, K.; Abe, Y.; Kitago, M.; Shinoda, M.; Kitagawa, Y. Decellularized liver scaffolds promote liver regeneration after partial hepatectomy. Sci. Rep. 2019, 9, 12543. [CrossRef] [PubMed]

164. Hodgson, M.J.; Knutson, C.C.; Momtahan, N.; Cook, A.D. Extracellular Matrix from Whole Porcine Heart Decellularization for Cardiac Tissue Engineering. In Decellularized Scaffolds and Organogenesis; Humana Press: New York, NY, USA, 2017 ; pp. 95-102.

165. Ohata, K.; Ott, H.C. Human-scale lung regeneration based on decellularized matrix scaffolds as a biologic platform. Surg. Today 2020, 50, 633-643. [CrossRef] [PubMed]

166. Xue, A.; Niu, G.; Chen, Y.; Li, K.; Xiao, Z.; Luan, Y.; Sun, C.; Xie, X.; Zhang, D.; Du, X.; et al. Recellularization of well-preserved decellularized kidney scaffold using adipose tissue-derived stem cells. J. Biomed. Mater. Res. Part A 2018, 106, 805-814. [CrossRef] [PubMed]

167. Damodaran, R.G.; Vermette, P. Decellularized pancreas as a native extracellular matrix scaffold for pancreatic islet seeding and culture. J. Tissue Eng. Regen. Med. 2018, 12, 1230-1237. [CrossRef]

168. Acikgöz, A.; Giri, S.; Cho, M.G.; Bader, A. Morphological and Functional Analysis of Hepatocyte Spheroids Generated on Poly-HEMA-Treated Surfaces under the Influence of Fetal Calf Serum and Nonparenchymal Cells. Biomolecules 2013, 3, 242-269. [CrossRef] 
169. Imaninezhad, M.; Hill, L.; Kolar, G.; Vogt, K.; Zustiak, S.P. Templated Macroporous Polyethylene Glycol Hydrogels for Spheroid and Aggregate Cell Culture. Bioconjugate Chem. 2019, 30, 34-46. [CrossRef]

170. Chen, Y.-H.; Wang, I.J.; Young, T.-H. Formation of Keratocyte Spheroids on Chitosan-Coated Surface Can Maintain Keratocyte Phenotypes. Tissue Eng. Part A 2009, 15, 2001-2013. [CrossRef]

171. Vinci, M.; Gowan, S.; Boxall, F.; Patterson, L.; Zimmermann, M.; Court, W.; Lomas, C.; Mendiola, M.; Hardisson, D.; Eccles, S.A Advances in establishment and analysis of three-dimensional tumor spheroid-based functional assays for target validation and drug evaluation. BMC Biol. 2012, 10, 29. [CrossRef] [PubMed]

172. Hasebe, Y.; Okumura, N.; Koh, T.; Kazama, H.; Watanabe, G.; Seki, T.; Ariga, T. Formation of rat hepatocyte spheroids on agarose. Hepatol. Res. 2005, 32, 89-95. [CrossRef]

173. Nie, Y.; Xu, X.; Wang, W.; Ma, N.; Lendlein, A. Spheroid formation of human keratinocyte: Balancing between cell-substrate and cell-cell interaction. Clin. Hemorheol. Microcirc. 2020, 76, 329-340. [CrossRef]

174. Goričan, L.; Gole, B.; Potočnik, U. Head and Neck Cancer Stem Cell-Enriched Spheroid Model for Anticancer Compound Screening. Cells 2020, 9, 1707. [CrossRef]

175. Baze, A.; Parmentier, C.; Hendriks, D.F.G.; Hurrell, T.; Heyd, B.; Bachellier, P.; Schuster, C.; Ingelman-Sundberg, M.; Richert, L. Three-Dimensional Spheroid Primary Human Hepatocytes in Monoculture and Coculture with Nonparenchymal Cells. Tissue Eng. Part C 2018, 24, 534-545. [CrossRef] [PubMed]

176. Hagemann, J.A.N.; Jacobi, C.; Hahn, M.; Schmid, V.; Welz, C.; Schwenk-Zieger, S.; Stauber, R.; Baumeister, P.; Becker, S. Spheroidbased 3D Cell Cultures Enable Personalized Therapy Testing and Drug Discovery in Head and Neck Cancer. Anticancer Res. 2017, 37, 2201. [CrossRef] [PubMed]

177. Ramaiahgari, S.C.; Waidyanatha, S.; Dixon, D.; DeVito, M.J.; Paules, R.S.; Ferguson, S.S. From the Cover: Three-Dimensional (3D) HepaRG Spheroid Model with Physiologically Relevant Xenobiotic Metabolism Competence and Hepatocyte Functionality for Liver Toxicity Screening. Toxicol. Sci. 2017, 159, 124-136. [CrossRef]

178. Ducker, M.; Millar, V.; Ebner, D.; Szele, F.G. A Semi-automated and Scalable 3D Spheroid Assay to Study Neuroblast Migration. Stem Cell Rep. 2020, 15, 789-802. [CrossRef]

179. Kessel, S.; Cribbes, S.; Déry, O.; Kuksin, D.; Sincoff, E.; Qiu, J.; Chan, L.L.-Y. High-Throughput 3D Tumor Spheroid Screening Method for Cancer Drug Discovery Using Celigo Image Cytometry. Slas Technol. 2016, 22, 454-465. [CrossRef] [PubMed]

180. Cho, M.O.; Li, Z.; Shim, H.-E.; Cho, I.-S.; Nurunnabi, M.; Park, H.; Lee, K.Y.; Moon, S.-H.; Kim, K.-S.; Kang, S.-W.; et al. Bioinspired tuning of glycol chitosan for 3D cell culture. NPG Asia Mater. 2016, 8, e309. [CrossRef]

181. Loessner, D.; Rockstroh, A.; Shokoohmand, A.; Holzapfel, B.M.; Wagner, F.; Baldwin, J.; Boxberg, M.; Schmalfeldt, B.; Lengyel, E.; Clements, J.A.; et al. A 3D tumor microenvironment regulates cell proliferation, peritoneal growth and expression patterns. Biomaterials 2019, 190-191, 63-75. [CrossRef]

182. Shang, M.; Soon, R.H.; Lim, C.T.; Khoo, B.L.; Han, J. Microfluidic modelling of the tumor microenvironment for anti-cancer drug development. Lab Chip 2019, 19, 369-386. [CrossRef]

183. Hoarau-Véchot, J.; Rafii, A.; Touboul, C.; Pasquier, J. Halfway between 2D and Animal Models: Are 3D Cultures the Ideal Tool to Study Cancer-Microenvironment Interactions? Int. J. Mol. Sci. 2018, 19, 181. [CrossRef]

184. Thippabhotla, S.; Zhong, C.; He, M. 3D cell culture stimulates the secretion of in vivo like extracellular vesicles. Sci. Rep. 2019, 9, 13012. [CrossRef]

185. Groebe, K.; Mueller-Klieser, W. On the relation between size of necrosis and diameter of tumor spheroids. Int. J. Radiat. Oncol. Biol. Phys. 1996, 34, 395-400. [CrossRef]

186. Anada, T.; Fukuda, J.; Sai, Y.; Suzuki, O. An oxygen-permeable spheroid culture system for the prevention of central hypoxia and necrosis of spheroids. Biomaterials 2012, 33, 8430-8441. [CrossRef] [PubMed]

187. Barros, S.; Costa, E.C.; Nunes, A.S.; de Melo-Diogo, D.; Correia, I.J. Comparative study of the therapeutic effect of Doxorubicin and Resveratrol combination on 2D and 3D (spheroids) cell culture models. Int. J. Pharm. 2018, 551, 76-83. [CrossRef] [PubMed]

188. Paškevičiūtè, M.; Petrikaitè, V. Differences of statin activity in 2D and 3D pancreatic cancer cell cultures. Drug Des. Dev. Ther. 2017, 11, 3273-3280. [CrossRef]

189. Aline, G.S.; Beatriz, B.S.I.; Esther, C.-F.; Leticia, S.B.; Brito, S.J.; Karina, M.; Luiz, R.G.; Vivian, A.-G. Comparative Assay of 2D and 3D Cell Culture Models: Proliferation, Gene Expression and Anticancer Drug Response. Curr. Pharm. Des. 2018, 24, 1689-1694.

190. Riedl, A.; Schlederer, M.; Pudelko, K.; Stadler, M.; Walter, S.; Unterleuthner, D.; Unger, C.; Kramer, N.; Hengstschläger, M.; Kenner, L.; et al. Comparison of cancer cells in 2D vs. 3D culture reveals differences in AKT-mTOR-S6K signaling and drug responses. J. Cell Sci. 2017, 130, 203. [CrossRef]

191. Luca, C.; Mersch, S.; Deenen, R.; Schmidt, S.; Messner, I.; Schäfer, K.-L.; Baldus, S.E.; Huckenbeck, W.; Piekorz, R.P.; Knoefel, W.T.; et al. Impact of the 3D Microenvironment on Phenotype, Gene Expression, and EGFR Inhibition of Colorectal Cancer Cell Lines. PLoS ONE 2013, 8, e59689. [CrossRef] [PubMed]

192. Kimlin, L.C.; Casagrande, G.; Virador, V.M. In vitro three-dimensional (3D) models in cancer research: An update. Mol. Carcinog. 2013, 52, 167-182. [CrossRef]

193. Zietarska, M.; Maugard, C.M.; Filali-Mouhim, A.; Alam-Fahmy, M.; Tonin, P.N.; Provencher, D.M.; Mes-Masson, A.-M. Molecular description of a 3D in vitro model for the study of epithelial ovarian cancer (EOC). Mol. Carcinog. 2007, 46, 872-885. [CrossRef] [PubMed] 
194. Loessner, D.; Stok, K.S.; Lutolf, M.P.; Hutmacher, D.W.; Clements, J.A.; Rizzi, S.C. Bioengineered 3D platform to explore cell-ECM interactions and drug resistance of epithelial ovarian cancer cells. Biomaterials 2010, 31, 8494-8506. [CrossRef] [PubMed]

195. Lee, J.M.; Mhawech-Fauceglia, P.; Lee, N.; Parsanian, L.C.; Lin, Y.G.; Gayther, S.A.; Lawrenson, K. A three-dimensional microenvironment alters protein expression and chemosensitivity of epithelial ovarian cancer cells in vitro. Lab. Investig. 2013, 93, 528-542.

196. Bielecka, Z.F.; Maliszewska-Olejniczak, K.; Safir, I.J.; Szczylik, C.; Czarnecka, A.M. Three-dimensional cell culture model utilization in cancer stem cell research. Biol. Rev. 2017, 92, 1505-1520. [CrossRef]

197. Chiew, G.G.Y.; Wei, N.; Sultania, S.; Lim, S.; Luo, K.Q. Bioengineered three-dimensional co-culture of cancer cells and endothelial cells: A model system for dual analysis of tumor growth and angiogenesis. Biotechnol. Bioeng. 2017, 114, 1865-1877. [CrossRef] [PubMed]

198. Kuen, J.; Darowski, D.; Kluge, T.; Majety, M. Pancreatic cancer cell/fibroblast co-culture induces M2 like macrophages that influence therapeutic response in a 3D model. PLoS ONE 2017, 12, e0182039.

199. Kurosawa, H. Methods for inducing embryoid body formation: In vitro differentiation system of embryonic stem cells. J. Biosci. Bioeng. 2007, 103, 389-398. [CrossRef] [PubMed]

200. Giobbe, G.G.; Zagallo, M.; Riello, M.; Serena, E.; Masi, G.; Barzon, L.; di Camillo, B.; Elvassore, N. Confined 3D microenvironment regulates early differentiation in human pluripotent stem cells. Biotechnol. Bioeng. 2012, 109, 3119-3132. [CrossRef] [PubMed]

201. Pettinato, G.; Wen, X.; Zhang, N. Engineering Strategies for the Formation of Embryoid Bodies from Human Pluripotent Stem Cells. Stem Cells Dev. 2015, 24, 1595-1609. [CrossRef] [PubMed]

202. Ludwig, T.E.; Levenstein, M.E.; Jones, J.M.; Berggren, W.T.; Mitchen, E.R.; Frane, J.L.; Crandall, L.J.; Daigh, C.A.; Conard, K.R.; Piekarczyk, M.S.; et al. Derivation of human embryonic stem cells in defined conditions. Nat. Biotechnol. 2006, $24,185-187$. [CrossRef] [PubMed]

203. Yoon, S.; Yoo, S.J.; Lee, J.E.; You, S.; Lee, H.T.; Yoon, H.S. Enhanced differentiation of human embryonic stem cells into cardiomyocytes by combining hanging drop culture and 5-azacytidine treatment. Differentiation 2006, 74, 149-159. [CrossRef]

204. Mohr, J.C.; de Pablo, J.J.; Palecek, S.P. 3-D microwell culture of human embryonic stem cells. Biomaterials 2006, $27,6032-6042$. [CrossRef]

205. Ungrin, M.D.; Joshi, C.; Nica, A.; Bauwens, C.; Zandstra, P.W. Reproducible, Ultra High-Throughput Formation of Multicellular Organization from Single Cell Suspension-Derived Human Embryonic Stem Cell Aggregates. PLoS ONE 2008, 3, e1565. [CrossRef] [PubMed]

206. Meng, X.; Leslie, P.; Zhang, Y.; Dong, J. Stem cells in a three-dimensional scaffold environment. SpringerPlus 2014, 3, 80. [CrossRef]

207. Regmi, S.; Pathak, S.; Thanh, T.P.; Nguyen, T.T.; Sung, J.-H.; Yook, S.; Kim, J.O.; Yong, C.S.; Choi, I.; Doh, K.-O.; et al. Intraportally delivered stem cell spheroids localize in the liver and protect hepatocytes against GalN/LPS-induced fulminant hepatic toxicity. Stem Cell Res. Ther. 2019, 10, 230. [CrossRef] [PubMed]

208. Sasai, Y. Next-Generation Regenerative Medicine: Organogenesis from Stem Cells in 3D Culture. Cell Stem Cell 2013, 12, 520-530. [CrossRef] [PubMed]

209. Liu, Q.; Wang, J.; Chen, Y.; Zhang, Z.; Saunders, L.; Schipani, E.; Chen, Q.; Ma, P.X. Suppressing mesenchymal stem cell hypertrophy and endochondral ossification in 3D cartilage regeneration with nanofibrous poly(l-lactic acid) scaffold and matrilin3. Acta Biomater. 2018, 76, 29-38. [CrossRef]

210. Yu, L.; Wu, Y.; Liu, J.; Li, B.; Ma, B.; Li, Y.; Huang, Z.; He, Y.; Wang, H.; Wu, Z.; et al. 3D Culture of Bone Marrow-Derived Mesenchymal Stem Cells (BMSCs) Could Improve Bone Regeneration in 3D-Printed Porous Ti6Al4V Scaffolds. Stem Cells Int. 2018, 2018, 2074021. [CrossRef]

211. Xu, L.; Wang, S.; Sui, X.; Wang, Y.; Su, Y.; Huang, L.; Zhang, Y.; Chen, Z.; Chen, Q.; Du, H.; et al. Mesenchymal Stem Cell-Seeded Regenerated Silk Fibroin Complex Matrices for Liver Regeneration in an Animal Model of Acute Liver Failure. Acs Appl. Mater. Interfaces 2017, 9, 14716-14723. [CrossRef]

212. Wang, K.-L.; Xue, Q.; Xu, X.-H.; Hu, F.; Shao, H. Recent progress in induced pluripotent stem cell-derived 3D cultures for cardiac regeneration. Cell Tissue Res. 2021, 164, 1-10.

213. Song, L.; Yuan, X.; Jones, Z.; Griffin, K.; Zhou, Y.; Ma, T.; Li, Y. Assembly of Human Stem Cell-Derived Cortical Spheroids and Vascular Spheroids to Model 3-D Brain-like Tissues. Sci. Rep. 2019, 9, 5977. [CrossRef]

214. Gizaw, M.; Faglie, A.; Pieper, M.; Poudel, S.; Chou, S.F. The Role of Electrospun Fiber Scaffolds in Stem Cell Therapy for Skin Tissue Regeneration. Med. ONE 2019, 4, e190002.

215. Jeena, K.; Manju, C.A.; Sajesh, K.M.; Gowd, G.S.; Sivanarayanan, T.B.; Mol, C.D.; Manohar, M.; Nambiar, A.; Nair, S.V.; Koyakutty, M. Brain-Tumor-Regenerating 3D Scaffold-Based Primary Xenograft Models for Glioma Stem Cell Targeted Drug Screening. ACS Biomater. Sci. Eng. 2019, 5, 139-148. [CrossRef]

216. Saengwimol, D.; Rojanaporn, D.; Chaitankar, V.; Chittavanich, P.; Aroonroch, R.; Boontawon, T.; Thammachote, W.; Jinawath, N.; Hongeng, S.; Kaewkhaw, R. A three-dimensional organoid model recapitulates tumorigenic aspects and drug responses of advanced human retinoblastoma. Sci. Rep. 2018, 8, 15664. [CrossRef]

217. Ranga, A.; Gjorevski, N.; Lutolf, M.P. Drug discovery through stem cell-based organoid models. Adv. Drug Deliv. Rev. 2014, 69-70, 19-28. [CrossRef]

218. Baptista, P.M.; Siddiqui, M.M.; Lozier, G.; Rodriguez, S.R.; Atala, A.; Soker, S. The use of whole organ decellularization for the generation of a vascularized liver organoid. Hepatology 2011, 53, 604-617. [CrossRef] 
219. Kim, Y.; Ju, J.H. Generation of 3D Skin Organoid from Cord Blood-derived Induced Pluripotent Stem Cells. JoVE 2019, 146, e59297. [CrossRef]

220. Wu, H.; Uchimura, K.; Donnelly, E.L.; Kirita, Y.; Morris, S.A.; Humphreys, B.D. Comparative Analysis and Refinement of Human PSC-Derived Kidney Organoid Differentiation with Single-Cell Transcriptomics. Cell Stem Cell 2018, 23, 869-881.e868. [CrossRef] [PubMed]

221. Völkner, M.; Zschätzsch, M.; Rostovskaya, M.; Overall, R.W.; Busskamp, V.; Anastassiadis, K.; Karl, M.O. Retinal Organoids from Pluripotent Stem Cells Efficiently Recapitulate Retinogenesis. Stem Cell Rep. 2016, 6, 525-538. [CrossRef] [PubMed]

222. Kelava, I.; Lancaster, M.A. Dishing out mini-brains: Current progress and future prospects in brain organoid research. Dev. Biol. 2016, 420, 199-209. [CrossRef]

223. Dutta, D.; Heo, I.; Clevers, H. Disease Modeling in Stem Cell-Derived 3D Organoid Systems. Trends Mol. Med. 2017, 23, 393-410. [CrossRef] [PubMed]

224. Boonekamp, E.; Kretzschmar, K.; Wiener, D.J.; Asra, P.; Derakhshan, S.; Puschhof, J.; López-Iglesias, C.; Peters, P.J.; Basak, O.; Clevers, H. Long-term expansion and differentiation of adult murine epidermal stem cells in 3D organoid cultures. Proc. Natl. Acad. Sci. USA 2019, 116, 14630. [CrossRef] [PubMed]

225. Hoang, P.; Wang, J.; Conklin, B.R.; Healy, K.E.; Ma, Z. Generation of spatial-patterned early-developing cardiac organoids using human pluripotent stem cells. Nat. Protoc. 2018, 13, 723-737. [CrossRef] [PubMed]

226. Tchieu, J.; Zimmer, B.; Fattahi, F.; Amin, S.; Zeltner, N.; Chen, S.; Studer, L. A Modular Platform for Differentiation of Human PSCs into All Major Ectodermal Lineages. Cell Stem Cell 2017, 21, 399-410.e397. [CrossRef]

227. Wilson, W.R.; Hay, M.P. Targeting hypoxia in cancer therapy. Nat. Rev. Cancer 2011, 11, 393-410. [CrossRef]

228. Minchinton, I.; Tannock, I.F. Drug penetration in solid tumours. Nat. Rev. Cancer 2006, 6, 583-592. [CrossRef]

229. Geraili, A.; Jafari, P.; Hassani, M.S.; Araghi, B.H.; Mohammadi, M.H.; Ghafari, A.M.; Tamrin, S.H.; Modarres, H.P.; Kolahchi, A.R.; Ahadian, S.; et al. Controlling Differentiation of Stem Cells for Developing Personalized Organ-on-Chip Platforms. Adv. Healthc. Mater. 2018, 7, 1700426. [CrossRef]

230. Cochrane, A.A.; Albers, H.J.; Passier, R.; Mummery, C.L.; van den Berg, A.; Orlova, V.V.; van der Meer, A.D. Advanced in vitro models of vascular biology: Human induced pluripotent stem cells and organ-on-chip technology. Adv. Drug Deliv. Rev. 2019, 140, 68-77. [CrossRef] 